UCRL-53549

Distribution Category UC-11

UCR!- -53585

9:ㄴ: 910306

\title{
Marine Plankton as an Indicator of Low-Level Radionuclide Contamination in the Southern Ocean
}

\author{
K. V. Marsh \\ R. W. Buddemeier \\ Manuscript Date: May 1984
}

\begin{abstract}
DISCLAIMER
This report was prepared as an account of work sponsored by an agency of the United States Government. Neither the United States Government nor any agency thereof, nor any of their employees, makes any warranty, express or implied, or assumes any legal liability or responsibility for the aceuiacy, completeness, or usefulness of any information, apparalus, product, of process disclosed, or represen's that its use would not infringe privately owned rights. Reference herein to any ipecilic commercial product, process, or service by trade name, trademark, manulacturer, or otherwise does not necessarily constitute or imply its endorsement, recommendation, or favoring by the United States Government or any agency thereof. The views and opinions or authors expressed herein do not necessarily state or reflect those of the United States Government or any agency thereof.
\end{abstract}

\section{LAWRENCE LIVERMORE LABORATORY University of California $\bullet$ Livermore. California $\bullet 94550$}


Abstract . . . . . . . . . . . . . . . . . . . . . . . 1 Introduction . . . . . . . . . . . . . . . . . . . . . . . . . . 2 Review of the literature . . . . . . . . . . . . . . . . . . . . 3 Advantages and Limitations of Biological Accumulators . . . . . . . . . 10 Project Description . . . . . . . . . . . . . . . . . . . . . 12

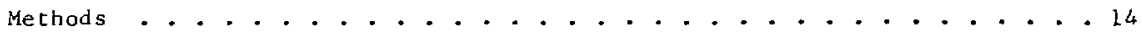

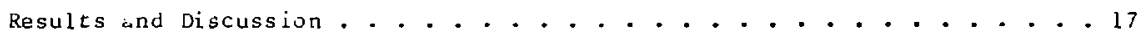
Resuspension . . . . . . . . . . . . . . . . . . . . . 33 Sunmary and conclusions . . . . . . . . . . . . . . . . . . . . 34 "urther Studies . . . . . . . . . . . . . . . . . . . . . . 30 Acknowledgments . . . . . . . . . . . . . . . . . . . . . . 36 References . . . . . . . . . . . . . . . . . . . . . . 37

\section{EICURES}

1. U.S. Coest Guard Cutter Glacier . . . . . . . . . . . . . . . 12

2. Cruise track for Operation Deepfreeze i981 . . . . . . . . . . . . 13

3. ylankton net setup for pumping. . . . . . . . . . . . . . . . . 15

4. 144 Ce concentration in latitude bands . . . . . . . . . . . . . . 18

5. ${ }^{95}$ Nb concentrations in latitude bands . . . . . . . . . . . . . 20

6. Plankton stations for Operation Deepfretze lybl . . . . . . . . . 24

7. ${ }^{3}$ Be concentrations at individual stations . . . . . . . . . . . . . 25

TABLES

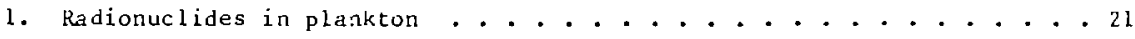

2. Plankton species... . . . . . . . . . . . . . . . . . . . . 28

3. Sutmary of biomass associated with artificial radinnuclides . . . . . 32 


\section{ABSTRALT}

We have initiated an investigation of the utility of marine plankton as hioconcentrating sauplers of low-level marint radiactivity in the southern hemisphere. A Literature review stows that both Ereshwater and inarine plankton have taace element and radionuclide concentration faccors (relative co water) of up to $10^{4}$. In the years 1956-1958, zonsidurable work was done on the accumulation and distribution of a varjety of figsion and activation products oroduced by the nuclear tests in the Harshall islands. Since then, itudies have largely been confined to a few selected radionuclides, and by iar most of this work has been done in the nurtisurn hemisphere. He participaled in operation Deepfreege l9dl, collecting 32 nlank-

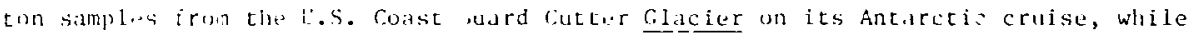

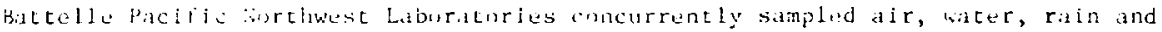
fallout. Se were able to measure concentrations of the raturally wearrinb radisnuclides 7 be, the and the $l$ and th series, and we beliave that we have detected low levels of lithe and 95 in in seven samples ranging as far south as bog. Ther:

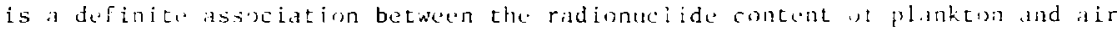
filters, supgesting that aerosol resuspension of marine radioalivity ma be mecurring. Biological identification of the plankton suggests a possible correlation between radionuclide concentr.tion and foraminiferi concent o: the samples. 


\section{IINTRODUCTION}

Atmospheric nuclear tests, reactor operations and waste disposal programs have injected significant quantities of radionuclides into the marine environment of the northern hemisphere. These releases have in general been documented, and considerable research has been done to characterize the tate of this radioactivity. The southern hemisphere, by contrast, has been gererally tree of radionuclide inpur with the exception of the nuclear tesis in the Tuamotus and some Jimited discharges of reactor cooling water. Relatively little sampling of the marine environnent has been done, especially in the open ocean, and only a few studies of atmospheric radionuclide concentrations, principally at Antarctica, have been carried out. We initiated this study to determine the levels of natural and antingopogenic racionuclides in the marine environment of the southern hemisphere, to identify and characterize their sources, and to develop more eftective sampling techniques.

Since the southern hemisphere is nearly all ocean. any radionuclides that are roleased will likely find their way into the marine environment where rapid dispersion and dilution will make them difficult to retect. While the fate of large releases either to the atmosphere or directly to the ocean could dossibly be predicted by compute lodels of atmospheric and oceanic transport in time for conzentrated samples to b'. collected, chronic low-levei sources cannot be so characterized and their contribution to the marine envi. nn nt is not predic. $3 b l e$. Fortunately, marine alankton, especially the phytoplankton, have la“ge concentration factors for many zrace clements and their radioactive isotopes. Furihermore, since they have relatively short lifetimes and are in constant equilibrium with the water in which they drift, they are excellent tracers of a parti.ular water mass. If the origin of the water mass and influence of currents is known, conclusions ran be drawn regarding the probable origin of the radioactivity. The marine plankton are particularly sensitive monitors of most anthropogenic radionuclides, having concentration factors of several hundred to several thousand for many elements. 
The characteristics of the radionuclides detected can be used to infer their source (for example, neutron-induced activicies, fission pi ducts or waste arocessing), while isocope ratios can give information regarding the age and origin of the debris. Truly quantitative measurements are difficult becaus a concentration and separation factors are not well known and are probably quite variable.

The influence of plankton in trace metal recyrling and the resultant ctfects on the composition ai the undorlying water colum and sediments is well documented. They tre the itst step in the concentration of trace and radioactive elements in the merine and ultinately human food chair, while their decomposition products wre matur contributurs to the sea surface microlayer and to the marine aerosol. Reidinutelides in plinklon an bie usid as cracers to qive more information concerning sume of thrse pencossus.

\section{WEYIE! , IF TIE I.ITERATURE.}

The prinipal conelusiun of aur computer-based literacure search was quirkly

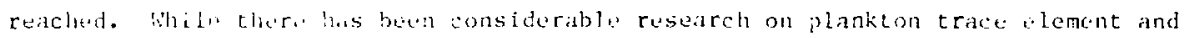
radionuclide accumblation in the northern hemisphere, there has boen virtually none in the southern hemisphere. What follows is i discussion of books and articles that we fool have particalar bearing on the problems of low-lavel radioartivity nonitoring ia the Southern Ocean.

Vo literature review, regardless of scope, would he adequace wichont mention of the 1964 book by polikarpov' that has become the classic in the field. Since then, several reports ${ }^{2}, 3$ have appeared that actually propo: e che use of various biological organisms to agnitor contamination by radion'clides, trace elements and even hydrocarbons. Ref. 2 is especially complete, containing a good discussion of reasons for using hioaccumulators rather than other techniques such as ion exchange resins. The difficulties inherenc in using bioa:cumulators, requirements for good bioaccumulators, and studies being undertaken at the time aro also discussed. 
By far most of the experience and data with a variety of radionuclides : $n$ marine plankton were acquired during the nuclear atmospheric test series at the Pacific Proving Grounds, Enewetak and Bikini in the Marshal1 Islands, from 1954 to 1958. Al1 of these data are contained in a series of reports ${ }^{4-7}$ and summarized in a very interesting and readable book. 8 While there are far too many daca from the Pacific programs to review, mention of a few significant experiments and results will give an indication of the potential utility of plankton as radionuclide monitors.

On May 16, 1958, the Wahoo event was detonated underwater two miles southwest of Enewetak. Plankton sampling was beg'n as soon as possible, and at $H+6$ hours the major part of the total radioactivity was found in the top $25 \mathrm{~m}$ and abcut one-eighth at the thermocline, $110 \mathrm{~m}$. By $H+28$ hours the activity was distributed through the upper half of the mixed layer to about $50 \mathrm{~m}$, but by $H+48$ hours it was concentrated at $100 \mathrm{~m}$, the upper edge of the thermocline. At no time was the activity uniformly mixed; it was always stratified. Gammaemitting short-lived fission products wete dominant immediately following the explosinn, and were (from May 16 to 20 ) ${ }^{99} \mathrm{Mo}$ and $132 \mathrm{Te}-132 \mathrm{I}$. Large plankton contained $140 \mathrm{Ba}$, while the smaller plankton had higher percentages of $999_{10-} 99 \mathrm{Tc}$. Measurements of the relative tutal radioactivity in filtered water and plankton showed the water inventory to be $3000-11,000$ times higher, indicating that plankt $\leadsto$ played a small part in removing the radioactivity. This was because the total a nount of plankton was very small compared with the water. Naturally occurring trace elements in seawater such as $\mathrm{Zn}, \mathrm{Co}, \mathrm{Ru}, \mathrm{Cs}, \mathrm{Sr}$ and I are usually presen: in solution, and their radioactive isotopes were found only in trace quantities in plankton. Those with the least solubility, such as ${ }^{95} \mathrm{Zr}$ and ${ }^{144} \mathrm{Ce}$ were found in the greatest amounts (Ref. 8, pp. 278 285).

While the experiments following the Whoo shot were confired to 1 small area and involved high levels of many fission products, other surveys were undertaken 
to look for low levels of radionclides throughout the North Pacif ic occan. A local survey 4 of the Pacific proving Grsunds during the test period in June 1956 consisted of a grid of stations $45 \mathrm{miles}$ apart covering an area of $78,000 \mathrm{sq}$. mi. Radioactive materials were found in planktun samples from every static. with the average concentration 7100 times the average surface water concentration. A much more extersive sursey involving lower levels of radiuactivity had been carried out the year bufore between Yarch 13, 1955, and Yay 3, 1955, one year after the Lests in the spring of 1954; this was nperatiun Troll. 5 The Cuast Guard Cutter Rouer B. Taney left Kwajalein on iarch 13, 1955, sampled the area of Browetak-Bikini and arrived in Guam on tarch 22, taking samples along the way. The ship then procecded northwest to about 220:139\% Philippines. From there the ship sailed to okinawa, on to Tokyo, and departed on April 21 : rom Yokosuka for San Franeisco, arriving on thy 3 . Samples were collectod all the way. The overall averige concentration factor for plankton relaEive to kit:r was 300 (range $(00)-1000$ ) and 80 )-90\% of the activiry was due to 1440. This nuclide and $95 \mathrm{Nb}$ constitute $26 \%$ and $14 \%$ respectively of the total radioactivity of onc-year-old ission products and esseltia? y all of the gamma radionctivity. ${ }^{9}$ The lowest concenteations were found near cle pacific Proving Grounds and the highest in the western Pacific around tho Philippines and okinawa. The microplankton, Less than $0.1 \mathrm{~mm}$, generally had the highest specific activity. Some pertinent conclusions of Operation Troll were: "The high specific activity uf plankton compared with seawater makes it a simple measure of the distribution of acivity" (p. 11) ... "Measurements of plankton activity offer a sensitive indication of activity in the ocean ..." and ..."Similar operations would be valuable in assessing the activity from future tests ard in gathering valuable data for oceanographic studies" (p. 13). 
Another survey ${ }^{6}$ conducted from Sept. 1-20, 1956, six weeks after the last test in the 1956 series, reported results similar to those cited. They also found a reduction in the concentration factor with time from 7000 to 300 and attributed it to a wider spectrum of radionuclides available at early times. Two other important conclusions were that plankton appears to be the most sensitive indicator of radioactivity in the sea, and microplankton is probably the principal source of radioactive particulate matter. Nuclides detected were $89,90^{\mathrm{Sr}}, 137,140 \mathrm{Ba}, 144 \mathrm{Ce}$, ${ }^{103} \mathrm{Ru}, 106_{\mathrm{Ru}}-106_{\mathrm{Rh}}, 95_{\mathrm{Zr}}, 57,58,60_{\mathrm{Co}}, 65_{\mathrm{Zn}}, 59 \mathrm{Fe}$ and trivalent rare earths. The last report in the series ${ }^{7}$ gives the results of some radiochemical separations made on plankton samples collected in and west of the Proving Grounds in September, 1956. "Fission products, mainly ${ }^{95} \mathrm{Zr}-95 \mathrm{Nb}$ and ${ }^{144} \mathrm{Ce}-144 \mathrm{Pr}$, contributed an average of $29 \%$ of the total radioactivity. The remaining $71 \%$ of the activity was contributed by the nonfission radioisatopes ${ }^{65} \mathrm{Zn}, 57,58,60 \mathrm{Co}, 55 \mathrm{Fe}$ and $54 \mathrm{Mn}$ [in quantities of $24,26,21$ percent and trace respectivelyl. Variations in ratio of occurrence for the different nonfission products with change in geographical location vere observed." This lajt observation was no doubt due to differences in source terms for activation products from different locations.

The last atmospheric test series, Operation Dominic, was conducted in 1962 at Christmas Island, and the biological investigations are summarized in Ref. 10 . Even though no tests were conducted in which the fireball touched the surface, so that little fallout was produced, plankton sampling showed elevated levels of a few fission products. The utility and sensitivity of plankton sampling were emphasized in the report by the facts that not only were $95 \mathrm{Zr}-95 \mathrm{Nb}, 141,144 \mathrm{Ce}$ and other radionuclides detected, but the levels increased as the test program continued. Analysis of seawater samples revealed no increase in either the number of radionuclides or in the levels of radioactivity during the period of the study. In fact, two-thirds of the water samples showed no detectable levels of radioactivity above background, and most of those that did had counting errors greater than $50 \%$. 
Since the cessation of nuclear testing in the atmosphere, reports have been concerned with inputs from world-wide fallout, nuclear fuel reprocessing wastes, releases from nucliar power plants, specific isotope studies and some related data from stable trace element studies. Ref. 10 includes studies of Mn, Co, Ag and Sb isotopes with a discussion of their correlation in various marine organisms. Ref. 1 I reports on two cruises taken to monitor leakage from che Nuclear Fnergy $A_{j}$ en $y$ (NEA), part of the Organization for Economic Cooperation and Development, dumping sites off the west coast of Spail. An interesting conclusion from this study is that the rate of biological vertical transpozt downwards is of the order oi magnitude of some years.

Several papers ${ }^{12-14}$ have been concerned with ${ }^{239}$ Pu anu other transuranic and alpha-emitting radionuclides. The paper by Pillai et al. 12 reports concentration factors for ${ }^{239}$ Pu from "red tide" organisms (660), green alga (1570), giant and palm kelp (770) and 1080) and mixed coastal zooplankton (2590). The paper by Gromov13 reports the results of experiments in the partitioning of the radionuclides $239 \mathrm{Pu}, 106 \mathrm{Ru}$, and ${ }^{99} \mathrm{Tc}$ by both natural anc' single species phytoplankton populations and ${ }^{137} \mathrm{Cs}$ by krill. The mechanism of accumulation of $239 \mathrm{Pu}$ and $210 \mathrm{Po}$ by the brown algae Ascophyllum nodosum and marine plankton was studied by Zlobin and Mokanu. 14 They demonstrated that the accumulation of 239 Pu by marine algae is an active process involving energy expenditure by the cell. Fowler and Aston 15 used $235 \mathrm{~Np}$ tracer to investigate the potential uptake of $237 \mathrm{~Np}$ by marine zooplankton. They showed that Np exists almost entirely as a soluble species in seawater and is less available for uptake than either plutonium or americium. The uptake is probably related to surface adsorption proccsses, and when Np is ingested with food it is not effectively assimilated by a euphausid crustacean. A survey of the total alpha-activity of marine plankton by Shannon l6 showed that most of the activity was due to the presence of unsupported $210 \mathrm{Po}, 5-6 \mathrm{pCi} / \mathrm{g}$ 
dry. Thorium isotopes were variable, but the uran um series elements other than $210^{\circ}$ o were about $0.6 \mathrm{pCi} / \mathrm{g}$ dry zooplankton and $1.8 \mathrm{pCi} / \mathrm{g}$ dry phytoplankton. The wet-to-dry ratio averaged 16 . Another survey of the relative amounts of natural and man-made alpha emitters in planktor was made by Paschoa et al.17

A study by Sick and Baptis +18 addressed particularly the concentration of Cd in the marine food chain and showed that the marine copepod Pseudodiaptomus coronatus incorporated ${ }^{109} \mathrm{Cd}$ at higher rates from ambient water than from phytoplankton Food. A very complete study by Knauss and Kul9 of the elemental composition of plankton and the content of natural radioactive dacay chain nuclides reported not only concentration factors but cross-correlation coefficients calculated for all possihle pairs of elements studied. They suggested that a biolngic mechanism is likely as an explanation for the Ce depletion in seawater relative to the other rare earth elements, based on its high concentration factor in marine plankton. Not all trace elements are concentrated by the plankton as indicated by the No work already cited. Two papers 20,21 report the non-accuralation of $95 \mathrm{~m} T \mathrm{c}$ in either the IV or VIJ oxidation states. TC, like Np, is predomitantly in solution as an ionic species in seawater.

When it comes to the southern hemisphere, very little work has been reported, especially regarding artificial radionuclide uptake. The work of Shannon 16 in the area of the Cape of Good Hope was concerned only with natural decay series isotopes. The paper by Kolesnikova et al. 22 reports finding $141,144 \mathrm{Ce},{ }^{95} \mathrm{Zr}-{ }^{95} \mathrm{Nb}$ and $103_{\mathrm{Ru}}$ in zooplankton collected in the region of Mururoa Atoll, the French nuclear testing area. Jennings 23,24 reports $55 \mathrm{Fe}$ in plarkton increasing from below detectable levels at $20^{\circ} \mathrm{N}$ up to $\$ 30 \mathrm{nCi}$ per gram of iron at $20^{\circ} \mathrm{S}$ and then decreasing along a track at $135^{\circ} \mathrm{W}$ longitude. The maximum is ne.ir Mururoa $\left(22^{\circ} \mathrm{S} 139^{\circ} \mathrm{W}\right)$. He renarks that: "The paucity of data on radioactivity in marine organisms from the Southern Hemisphere is a serious deficiency because atmospheric nuclear tests are actively 
being carried out there."24 Ref. 23 is a disı ussion of the selective uptake by marine plankton of ${ }^{55} \mathrm{Fe}$ relative to other forms of stable Fe. It is interesting that our keyword search did not uncover a single reference similar to the University of Washington Fisheries Laboratory (UWFL) series on marine radioecology in connection with the Yururoa tests.

Freshwater organisins also have high concentracion factors for many elements, and our literature search found several interesting references. The survey by Blaylock ${ }^{25}$ summarizes the availability or data on concentration factors for use in dose assessment in the transfer of radionuclides from the aquat ic environment to man. Faztors influencing the variability of bioaccumulation concentration are identificd, uncertainties associated with the validation of thesc factors are discussed, and some guidance is given for collecting data and making measurements. Aoyama et al. 26 followed the uptake and reluase of ${ }^{137} \mathrm{Cs}, 65 \mathrm{Zn},{ }^{60} \mathrm{Cu}$ and ${ }^{45} \mathrm{Ca}$ by a fresh-water phytoplankton. They found thai the uptake is a biclogical process dependent on light and the growth phase. Marciulionientet al.27 also found that the accumulation of $90 \mathrm{Sr}, 144 \mathrm{Ce}, 137_{\mathrm{Cs}}$ and $106 \mathrm{Ru}$ in Charophyta depends on the species and that the accumulation of ${ }^{90} \mathrm{Sr}$ and ${ }^{137} \mathrm{Cs}$ depends on sampling time and vegetative period. Jenckes ${ }^{28}$ investigated the feasibility of developing a quantitative method for measuring low leveis of radionuclides in frush-water systems through bioaccuilulation, particularly by phytoplankton. An interesting report by Millard et al.29 presented the results of an irvestigation of the radionuclide content and cycling in the leaching ponds adjacent to the Test Reactor Area located at the Idaho National Engineering Laboratory. These ponds were small enough and inputs were known well enough to do material balance studies among the witer, surface sediments, seston, zooplunkton, benthic periphyton, macrophytes, littoral vegetation, arthropods and small mammals as a function of suasonal variation. As an indication of the potential various organisms have for use as bioaccumulators, 
the paper by Lavis ${ }^{30}$ discus:es the accumulation of several radionuclides by aquatic insect larvae as well as planktor. in the Columbia River. The concentration factors wire dependent on the grcath stages and water cenperature but were often 1000 or more for the nuclides ${ }^{32} \mathrm{~F},{ }^{51} \mathrm{Cr},{ }^{64} \mathrm{Cu},{ }^{65} \mathrm{Zn}$ and ${ }^{75} \mathrm{As}$.

Our iiterature review to dats has served to oriznt us with respect to the types of work being done, the methods used and results achieved. This helps us to plan our own research and gives some indication of how te might proceed and results we can expect.

\section{ADVANTAGES AND LIMITATIONS OF BIOLOGICAL ACCUNULATORS}

From both the literatere review and our own experience in radiochemical analysis, we can identify areas of sirergth and 'cakness in the ise of plaskton as a monitor for low levels of radioactivity in the sea. On the positive side, the various reports from the UlJf work show that uptake is rapid relwtive to dispersal and filution, and once it nas occurred, recycling keeps the radioniclides in the biotic layers and retards losses. These processes also assure us that the olankton is a unique rracer for a particular water mass as evidenced by the great distances over which it was followed by the University of ilashingt:s groups. The concentration factors are high enough to give cood sansitivity; our experience indicates plankton sampling provides a detectior. capability of the orcer of 0.1 pCi per liter of sea water. Furthermore, these high concentration factors exist for a wide range of nuclides, the principal exceptions veing only those species in true solutinn and th major elements in sea water. From a more practical standpoint, we can collect plankton in the open ncean, without infringing on any political boundaries, and with a knowledge of ocean current pattelns we can infer the origin of the water mass being sampled. Once a sea-going vessel is acquired, further equipmeal for plankton sampiing is very simple, iechniques are well worked out, ard the final samples are casily transported, stored, and analyzed. 
The principal disadvantage of plankton, or any bioaccumulator, is that calibration sufficiently accurate to produce quantitative data is very difficult. While some attempts have been made and procedures suggested $2,3,28$ for calibration, the concentration factors may depend on uncontrollable or unknown circumstances, such as the species involved, growth stages and bioavailabilty. While ratios between isotopes of the same elements should be consistent, even here caution should be exercised as evidenced by the 55 Fe specific activity result: of Jennings. 23 Isotope discrimination effects are probably reduced over time, and we wuld expect that as long as the adionuclides are all of approximately the same age, differrences should be sinall. Isotape ratios can b useful in estimating the age of the radioactivity and its origin, since the isotopic mixture in nuclear exposion debris is considerably different from that found in ruator or reprocessing efiluent. In any rase, with experience and some idea of the concentratinn factors involved, initial plankton analysis could be used to determine locations and procedures for sea water analysis by more quantitative techniques.

\section{$\because \quad$ PROJECT DESCRIPTION}

Our initial goals for the program were principally to obtain experience at plankton sampling, acquire tic necessary equipment, establish contacts with the oceanographic conmunity related to our work, and collect and analyze some samples from the southern hemisphere. Ue needed to investigate both scientific and logistical problems. Our analysis was to be principally by low-ievel $r$-spectroscopy on cntire samples, and we were concernd that natural levels of the $U$ a:d Th series as well as $40_{\mathrm{K}}$ might raise the background sufficiently to make detection of low levels of artificial radionuclides difficult or impossible.

We were funded concurrently with Battelle Pacific Northwest Laboratories (PNL) to make an investigation of the problems. PNL arranged for space on the U.S. Coast 
Guard Cutter Glacier (Fig. 1) for its "Operation Deepfreeze 1981" and provided personnel for most of the sampling trip. The general route of the ship after departure from Long Beach, California, in November 1981, was to !lawai east coast of Australia, New Zealand, the Ross Sei, eastward along the ice to Palmer Peninsula and after several trips back and forth between Palmer and Punta Arenas, north along the west coast of South America and back to Long Beach in :lay of 1982 (Fig. 2). Battelle had its own personnel on bodrd from Hawai to New Zealand, ani the remainder of the samples were taken by a Coast Guard marine technician trained by Battelle. In addition to our plankton samples, PNL also cnllected air filter samples, fallout, and large-volume water samples. The following year w: participated in a similar projecr, "Operation Deepfreeze 1982," which will be the subject of Part 2 of this report.

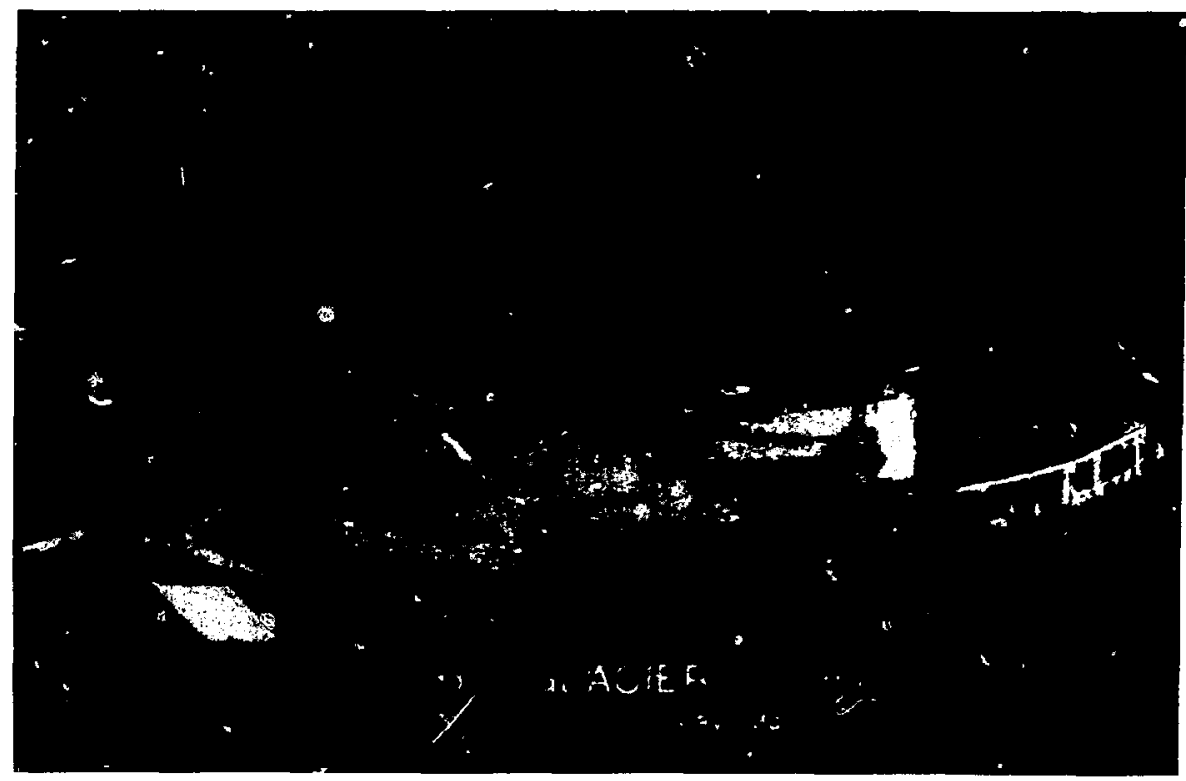

Figure 1. U.S. Coast Guard Cutter Glacier. 


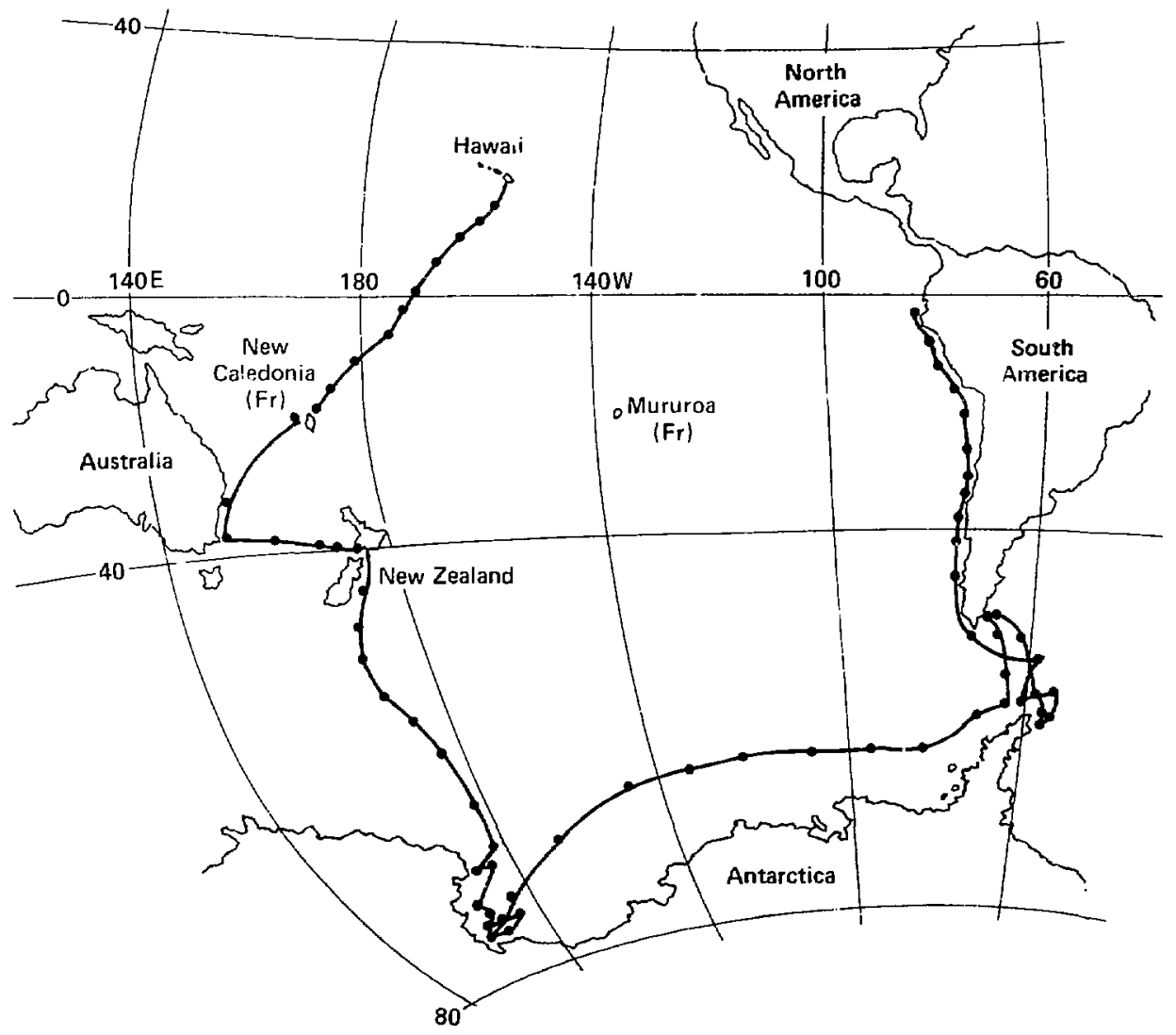

Figure 2. Cruise track for Operation Deepfreeze 1981. Dots indicate a sampling station of some type (air, fallout, rain, plankton, water). 


\section{METHODS}

Funding for this initial project began as of october 1, 1981, which left us little time to acquire equipment for plankton collecting. We were able to assemble barely the minimum necessary and transport it to Honolulu in lime to load aboard the Glacier by the First week in Noverber.

All the plankton samples were collected by pumping water through the ship's fire mains and filtering it through a No. 10 plankton net suspended in a 55 -gal drum chained outboard to the side of the ship. The net originally supplied was longer than the barrel was deep so the cod end was led back up and over the edge of the drum (Fig. 3). Later samples were collected in nets construated to fit the drums that we were able to obtain and send to the ship in Wellington. The fire mains delivered about 250 gal/min directly into the net through a 3-in. canvas hose. The water flowed through the net into the drum, which when full acted as a cushion, and then simply overflowed into the sea. Pumping was generaliy carried out over a 24-h period, but various problems caused by other shipboard operations often resulted in the pumps cycling on and off or in reduced flow, requiring longer sampling times. Volumes were estimated by periodicall: reading the water pressure after rough calibration of the system by noting the time required to till the drum at different pressures. Sample location and total volume were estimated by observing the time and position when sampling was started and concluded. While this arrangement was far from ideal, it produced fairly consistent samples atier several days of practice. On two occasions the barrel and net were lost because of heavy seas. After the samples were collected from the net, they were preserved in $5 \%$ buffered formalin in sea water for storage and transport. Volumes of sea water filtered varied from 250,000 gals to over one million gal in two cases with the average around 350,000 gal. Plankton wet weights were highly variable ranging from $25 \mathrm{~g}$ to $400 \mathrm{~g}$ with the average around $200 \mathrm{~g}$. As the samples were collected, 25-m1 subsamples were taken for species identification. 


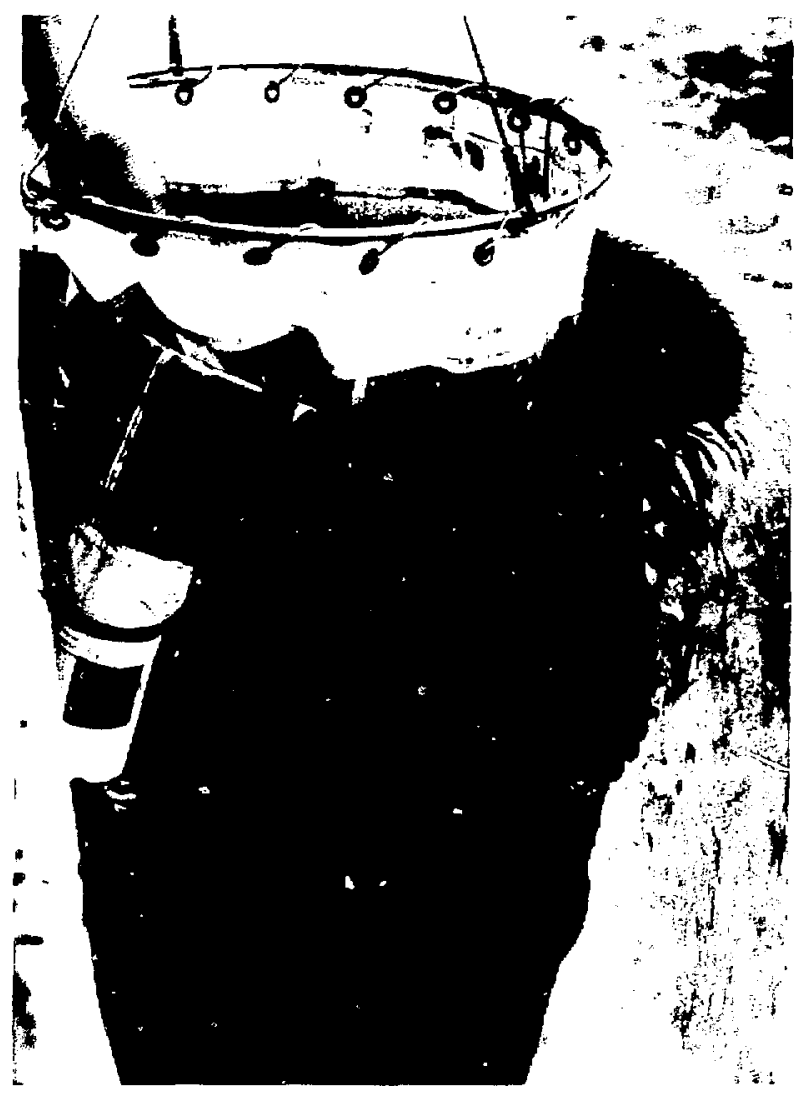

Figure 3. Plankton net setup for pumping. Note fire hose input at top left.

Dr. Wim Kimmerer of the University of Hawaii Institute of Marine Biology performed the spec 1.s identification on the initial 11 samples. He first counted large organisms such as euphausiids in the entire sample, then took aliquots using a plankton splitter and counted everything in this aliquot. All counts were converted to number of individuals per original subsample. Professor John Wormuth 
of Texas A\&M University, Department of Oceanography, identified the species in the remainder of the samples. He first sorted them by size, using Nytex screens, and courted total organisms, or if there were too many to count in a single size fraction, took an aliouot with a plankton splitter.

The first 11 samples were returned to Livermore from New Zealand by air in mid-January 1982; the remainder returned with the Glacier in tnid-May. The samples wer drained on a Nytex screen and weighed wet without rinsing. The plankton was recombined with the drained liquid and the whole sample taken to dryness in an oven at $110^{\circ} \mathrm{C}$. After drying, the samples were ground and homogenized with a mortar and pestle and packed into a suitable standard container for $\gamma$-spectroscopy. Al1 samples were counted on our low-background Compton-suppressed $\gamma$-spectrometer 31 for at least $10^{4} \mathrm{~min}$. The resulting spectra were computer-analyzed by the GAMANAL 32 code and results expressed as pico Curies per gram wet weight. Radionuclides were ail decay-corrected to the common time of December 1, 1981. This is a standard procedure in radjoecological studies that facilitates comparison of radioactivity ievels among samples collected over an extended time period and does not imply that December 1, 1981, was the date of production of any of the radionuc $\perp$ ides.

We were able to calculate upper limits, or detection limits, fnr any radionuclide not positively identified and measured. Because it was not feasible to calculate limits for all possible radionucilides that could be expected, we settled on those that were positively identified in at least one sample $\left({ }^{7} \mathrm{Be}\right.$, $95_{\mathrm{Nb}}, 144 \mathrm{Ce}$ ), and a few more that were known to have high concentration factors in plankton $\left(54 \mathrm{Mn}, 65 \mathrm{Zn}, 103_{\mathrm{Ru}}\right) .241_{\mathrm{Am}}$ was included in the upper 1 imit calculations because it is an indicator of ${ }^{239} \mathrm{PJ}$, which is of considerable interest to marine radioecologists. We did not calculate upper limits for any of che naturally occurring radionuclides, because their detection is not indicative of anthropogenic contamination. A detailed description of the procedure used by GAMANAL 
to calculate upper limits is given in Ref. 33, but a brief discussion will serve to show the type of upper limit used. If no peak is found in the r-spectrum rorresponding to the hrown energy of one emicted by the nuclide in question, the counts in the channels where the peak should be (due principally to the Compton continuum from higher energy peaks) are summed, the sciare root taken and rultiplicd by two. This quantity is then corrected by subsequent calculations for geometry, absorption, and decay and a concentration calculated just as if a peak had been found. The philosophy behind the method is that if, in the region of interest, counts exceeding twice the standard deviation of the background has been present, the puak-finding routine of GAMANAL would have identified a peak. For uclides emitting more than one r-ray, up to four such regions can be used, and the lowest value reported as the upper limit.

No significant oceanographic data were taken on this cruise as we were not equipped to make the measurements and only weather observations were taken by the Coast Guard. The Battelle air samplers were mounted as high as possible and run cuntinuously with filter paper changed at irregular intervals. Battelle also collected dry fallout on a $6-\mathrm{m}^{2}$ corrugated aluminum collector by washing the surface with a spray of water and collecting it along with any rain water every 24 hours. Battelle also collected high-volume water samples at the rate of 30 $1 /$ min rith a sampler of their own design. It will publish its own report on the results of its measurements.

\section{RESUL'S AND DISCUSSION}

The locations of all the plankton samples and the results of the $\gamma$-spectrometry analyses are given in Table 1. The two most interesting radionuclides detected are ${ }^{144} \mathrm{Ce}$ and $95 \mathrm{Nb}$. In most cases, both these nuclides were measured at concentrations above upper limir values; in other cases they were near detection Iimits. 
In the case of $144 \mathrm{Ce}$, only the gamma ray at $133.5 \mathrm{keV}$ was detected. This gama-ray has an overall abundance of $11 \%$ in the ${ }^{144} \mathrm{Ce}$ decay scheme; while there are others, their abundances are less by factors of 7 to 38 . A: the count rates we found for the $133.5 \mathrm{keV}$ photon, we could not exnect to find those with lower yields. We believe the ${ }^{144} \mathrm{Ce}$ to be real because there are no uther reasonable candidates for the $133.5-k e V$ photon, the ${ }^{144} \mathrm{Ce}$ is found by Battelle in its air filters, and it is known to have a high concentration factor ${ }^{4-7}$ in piankton. The $144 \mathrm{Ce}$ results for plankton along with the air filter data are shown in Fig. 4.

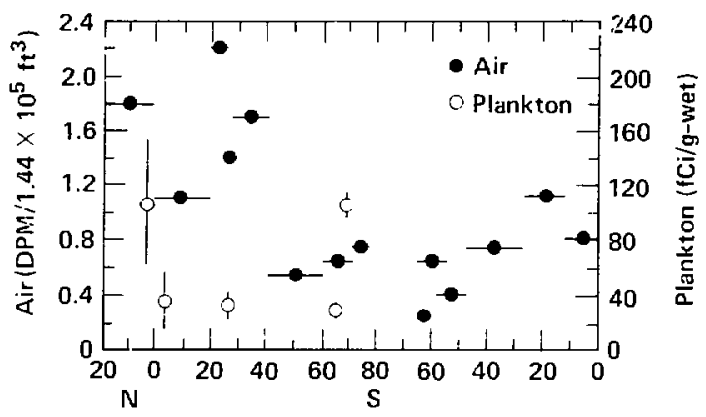

Route south Degrees of latitude Route north

Figure 4. ${ }^{144} \mathrm{Ce}$ concentrations in latitude bands. Horizontal bars indicate distance covered during collection. Vertical error bars are 1 o counting error (not available for air).

The air filter samples vere collected continuously and sometimes over a considerable distance, while the plankton samples were generally collected over only a relatively short distince. Because the stations are plotted at the mirpoint of the collection, they are not directly comparable on a station-by-station basis. In Fig. 4, the horizontal bars indicate the distances sailed during the collection. The abscissa 
shows degrees of latitude, with the left side the route south, and the right sice the return cruise north. There is a general relationship between the ${ }^{144} \mathrm{Cn}$ detected in the air and in the plankion. The higher levels in the air from about $20^{\circ} \mathrm{N}$ to $40^{\circ} \mathrm{S}$ on the western side of the basin (route south) are reflected in plankton from similar locations. Once the ${ }^{144} \mathrm{Ce}$ concentration falls below about $1.1 \mathrm{dpm} / \mathrm{sample}$ (normalized) in the air, however, it is .ot observed in the plankton (presumably below detection limits) except for the region between $60^{\circ}$ and $70^{\circ} \mathrm{S} . \quad 144 \mathrm{Ce}$ in plankton in this band may represent higher oceanic content independent of local atmospheric input, as $14^{4} \mathrm{Ce}$ and other radionuclides were detected by Battelle in water but not in air samples from this area. These other radionuclides were $110 \mathrm{~m}_{\mathrm{Ag}}$ $\left(2-5 \mathrm{dpm} / \mathrm{m}^{3}\right),{ }^{155} \mathrm{Eu}\left(3 \mathrm{dpm} / \mathrm{m}^{3}\right)$, and ${ }^{241} \mathrm{Am}\left(3 \mathrm{dpm} / \mathrm{m}^{3}\right)$. The overlapping locations between $45^{\circ}$ and $65^{\circ} \mathrm{S}$ on the east side of the basin (route north) represent samples collected during several transects of Drake Passage and indicate che range of concentration observed.

Figure 5 shows the equivalent data for ${ }^{95} \mathrm{Nb}$. The arguments for and against the detection of ${ }^{95} \mathrm{Nb}$ are somewhat more complicated than those regarding $144 \mathrm{Ce}$. The only gamma ray detected from 95 ivo is the 755.8 -ikeV photon, an energy similar to those of ${ }^{238_{\mathrm{U}}}$ (actually its granddaughter ${ }^{234} \mathrm{~Pa}$ ) at $766.4,102 \mathrm{~m}_{\mathrm{Rh}}$ at 767.0 , and $226_{\mathrm{Ra}}$ at 768.4 . 226 $\mathrm{Ra}$ can be eliminated on several grounds: the energy is too different to actually constitute an interference given our resolution; the GAMANAL program would have found other Ra $\gamma$-rays that are much morc abundant, and used them for appropriate corrections, and finally, Ra is not particularly concentrated by plankton. Several samples had detectable levels of $226_{R a}$ with only average upper limits calculated for ${ }^{95} \mathrm{Nb}$. The $102 \mathrm{~m}_{\mathrm{Rh}}$ can be eliminated on two grounds: it also has other $Y-r a y s$ in much higher abundance that were not detected, and it is neither

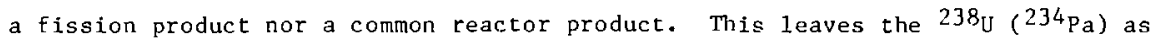
the principal candidate for interference. As can be seen in Table l, all the positive results for $95 \mathrm{Nb}$, except Sample 39 , are associated with the higher levels of 


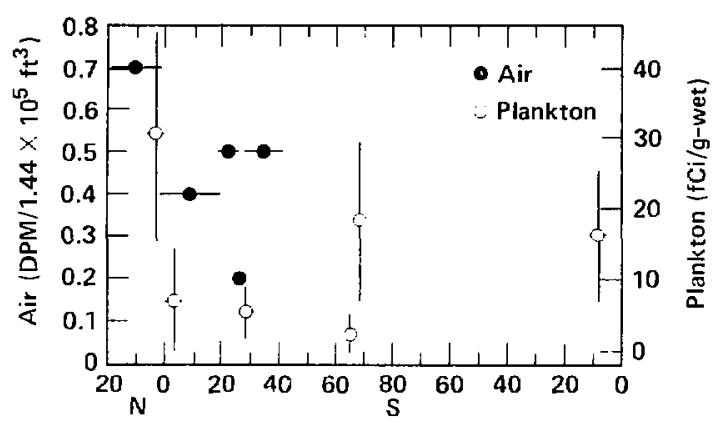

Route south Degrees of latitude Route north

Figure 5. $95 \mathrm{Nb}$ conrentrations in latitude hands. Horizontal bars indicate distarce covered during collection. Vertical error bars are 10 counting error (not available fur air).

${ }^{238} \mathrm{U}$. However, our experience with the GAMANAL program over many years and hundteds of samples, such as Livermore Valley soil containing $238 \mathrm{U}$ but no $95 \mathrm{Nb}$, has convinced us that the program accurately accounts for the $766.4-k e V ~ r-r a y n f 233_{1 j}$ by means of the associative $\gamma-$ rays at $b 3.3,92.6$, and $1100 l .1 \mathrm{keV}$ when counting statistics are good. In the plankton samples the total counts in the 7 b6 peak are very low, so the peak errors are large and the shapes not usually perfect. To be on the safe side, 95 Nb is only reported where the excess of the 766.4 peak over that contributed by $238 \mathrm{U}$ is 50 percent or more. Another slightly disturbing finding is that we do not detect the gamma rays from $95 \mathrm{Zr}$, the parent of $95 \mathrm{Nb}$. There could be several reasons for this, any one of which would be sufficient: the i-rays from $95 \mathrm{Zr}$ are lower in abundance by about a factor of two, the equilibrium disintegration rate of ${ }^{95} \mathrm{zr}$ is less than half. that of tine $95 \mathrm{Nb}$ and there is some indication that mo:e $95 \mathrm{Nb}$ than $95 \mathrm{zr}$ is released to the marine environment. Because the ${ }^{95} \mathrm{Nb}$ is barely detectable, any factor of two less for the ${ }^{95} \mathrm{zr}$ would make it undetectatle. In Fact, upper-limit values calculated for $95 \mathrm{Zr}$ are consistent with the $95_{\text {Nb }}$ measured. 
Table 1.

Radionuclides in $\mathrm{p}^{1}$ inkton.a,

\begin{tabular}{|c|c|c|c|c|c|c|c|c|c|c|c|c|c|c|}
\hline Sample & -7 & $K-40$ & -54 & -65 & $\mathrm{Nb}-95$ & -103 & Ra-22G & iRa-228 & $111-238$ & $A m-241$ & $\mathrm{Ce}-1441$ & Th-2 & 3) $U-235$ & ton \\
\hline $\begin{array}{l}\text { half- } \\
\text { life }\end{array}$ & $.6 \mathrm{~d} 1$ & $\begin{array}{l}1.27 \\
\times 10^{9}\end{array}$ & $312 d$ & $245 \mathrm{~d}$ & $\begin{array}{l}35.1 \mathrm{~d} \\
(64 \mathrm{~d})\end{array}$ & $40 d$ & $2 Y 1$ & $15.8 Y$ & $\begin{array}{l}14.51 \\
\times 10^{9} \mathrm{Y}\end{array}$ & $433 \mathrm{Y}$ & & $\begin{array}{l}1.40 \\
\times 10^{10} \mathrm{Y}\end{array}$ & $\begin{array}{r}7.04 \\
Y \div 10^{8} Y\end{array}$ & \\
\hline 1 & $|<0 .+48|$ & $\begin{array}{r}\div 10 \\
1.8 \overline{8}\end{array}$ & & & 10.0306 & .023 & & & $6 . \frac{+8}{31}$ & & $\begin{array}{c}+42 \\
.107\end{array}$ & & 1,100 & \\
\hline 2 & $\begin{array}{l}+35 \\
0.174\end{array}$ & 1.31 & $1<0.004$ & $\mid<0.0010$ & $\begin{array}{r}+35 \\
0.00706\end{array}$ & $1<0.014$ & $0.01 \frac{+50}{56}$ & $10.02 \frac{180}{20}$ & $\begin{array}{r}+37 \\
1.97 \\
\end{array}$ & |<0.031 & 0.03641 & - & -- & $6 \mathrm{~S} 17$ \\
\hline 3 & $\mid<0.108$ & $\mathrm{j}_{2}, 2 \overline{0}$ & $1<0.002$ & .004 & $<0.008$ & $1<0.066$ & -- & -- & $\begin{array}{r}+7 \\
0.5 \overline{9} 2 \\
\end{array}$ & ii & .017 & $=$ & - & $115 \mathrm{~s}$ \\
\hline 4 & .257 & $1,2 \frac{ \pm 6}{4}$ & $\mid<0.004$ & & 8 & & - & -- & $10.25 \frac{+25}{4}$ & & 038 & - & $=$ & $\{24$ \\
\hline 5 & $<0.102$ & $1.2 \overline{0}$ & $1<0.002$ & 2 & $1<0.006$ & $1<0.064$ & -- & -- & $\begin{array}{l}1+16 \mid \\
0.1754\end{array}$ & & $0.0 \overline{328}$ & - & -- & $26 s$ \\
\hline 6 & $0.3 \frac{11 \overline{4}}{6} 8$ & $1.1 \frac{15}{1}$ & $\mid<0.002$ & $1<0.006$ & $10.00 \frac{+68}{534}$ & $\mid<0.009$ & $\begin{array}{c}+180 \\
0.00 \overline{9}\end{array}$ & $10.01^{\frac{+32}{7}}$ & $11.98^{ \pm 17}$ & & & -- & -- & \\
\hline 7 & $0.3 \frac{+20}{360}$ & 1,45 & & & 04 & 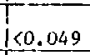 & -- & -- & $10.18^{+11}$ & & & $=$ & $=0$ & \\
\hline 8 & $0.2 \overline{7} 5^{4}$ & $1.0 \frac{+4}{14}$ & $1<0.001$ & 3 & 03 & 006 & $10.00 \overline{7} 7$ & $10.01^{\frac{t^{3}}{4}}$ & $1.04^{ \pm 7}$ & & 14 & -- & $=$ & $35 \mathrm{~S} 156$ \\
\hline 9 & $\begin{array}{r}+4 \\
0.19 \\
\end{array}$ & $1.1^{\frac{17}{2}}$ & $1<0.003$ & $1 \leq 0$. & 0.009 & 6 & - & -- & $1.30^{ \pm 7}$ & & 34 & - & -- & $36 \mathrm{~S} 159 \mathrm{E}$ \\
\hline 10 & $0.2 \overline{9} 2$ & $11.41^{+16}$ & $\mid<0.0005$ & & 02 & & -- & -- & $10.18 \overline{7}^{+18}$ & & & - & - & 37 \\
\hline 11 & $4 \frac{+17}{50}$ & $1 . \frac{+6}{5}$ & $1<0$ & & 002 & & 10.0143 & - & $12: 42^{ \pm 7}$ & & & -- & - & 395 \\
\hline 13 & 148 & $1.92^{4}$ & $1 \leq 0.001$ & $1<0.003$ & 50.011 & $1<0.008$ & $0.28 \frac{+7}{4}$ & -- & $\begin{array}{r}+7 \\
0.02 \overline{8} 4\end{array}$ & & $1<0.010$ & $=-$ & $=$ & $143517+8$ \\
\hline 14 & 626 & $14.29^{ \pm 7}$ & $1<0.005$ & & $<0.040$ & 82 & 10.0422 & -- & $10.63 \overline{5}^{+14}$ & & & $=$ & $=$ & 465 \\
\hline 16 & 85 & $1.22^{ \pm 5}$ & 01 & $1<0$ & 11 & 68 & $\begin{array}{r}+68 \\
0.00802\end{array}$ & $10.01^{\frac{+4}{5} 4}$ & $10.09^{\frac{+1}{4}} 3^{7}$ & & $\mid<0.008$ & -- & -- & $154 \mathrm{~S} 170 \mathrm{E}$ \\
\hline 17 & $1<0.178$ & $11.54^{ \pm 3}$ & $i<0.001$ & $1<0.002$ & $<0.011$ & 160.165 & -- & -- & $\begin{array}{r}+26 \\
10.0430 \\
\end{array}$ & 004 & $1<0.008$ & -- & -- & $1585.73 \mathrm{E}$ \\
\hline $18 \mathrm{c}$ & $<0.139$ & 1.06 & $<0.0008$ & $1<0.002$ & $\leq 0.008$ & $1<0,162$ & $0.00^{\frac{+13}{5}}$ & -- & $0.06 \overline{0} 0$ & & $1<0.006$ & -- & -- & $175 \mathrm{E}$ \\
\hline $18 \mathrm{~A}$ & $i<0.475$ & $11.04^{ \pm 3}$ & $<0.0007$ & $1<0.002$ & 120.021 & $1<0.938$ & 0.005 & -- & $10.04 \frac{+17}{12}$ & & $1<0.006$ & $1-$ & 10.00026 & $\begin{array}{l}17 \mathrm{SE} \\
161.5 \mathrm{~S}\end{array}$ \\
\hline
\end{tabular}

a The units are $\mathrm{pCi} / \mathrm{g}$ of wet plankton; values preceded by "<" Indlcate the upper Limit. Values are correcte! for decay to $12 / 1 / 81$.

b Errors are one standard deviaton (in percent).

c Sample 18 wis ilvided into two patts for counting purposes. 
Table 1 (concluded).

Radionuclides in plankton.

\begin{tabular}{|c|c|c|c|c|c|c|c|c|c|c|c|c|c|c|}
\hline Sample & $\mathrm{Be}-7$ & $k-40$ & $9 n-54$ & $2 n-65$ & $\mathrm{Nb}-95$ & $k_{u}-103$ & $a-22 b$ & $K a-28$ & $\underline{4}-238$ & $A M-241$ & $|\mathrm{Ce}-144|$ & $\mathrm{Th}-228$ & $u-235$ & Location \\
\hline 19 & $1<0.176$ & $10.88 \overline{8}$ & $|<0,0036|$ & $\leq 0.0016$ & $\begin{array}{r}+29 \\
0.00233 \\
\end{array}$ & $1<0.0$ & $=-$ & & $\left.10.42 \frac{+6}{7}\right\}$ & -- & $\mid \begin{array}{l}+16 \\
1.0286\end{array}$ & 10.00394 & $10.0 \frac{+11}{164}$ & $\begin{array}{l}1653 \\
1178.5 \mathrm{E}\end{array}$ \\
\hline 20 & $\mid<0.349$ & $0.77^{+4}$ & $\leq 0,0008 \mid$ & S. & $\begin{array}{r}+18 \\
0.0181\end{array}$ & 50.416 & & $0+\frac{+30}{32}$ & $10.820^{6}$ & .004 & $|0.105 \overline{5}|$ & 10.0179 & $\begin{array}{l}10.04 \\
10.0346\end{array}$ & $\begin{array}{l}685 \\
1179.7 \mathrm{E}\end{array}$ \\
\hline 22 & $\mid<0.499$ & $12.37^{+4}$ & $<0.0021$ & $<0.01963$ & $1<0.0296$ & $1<0.749$ & & & 0.114 & $\mid<0.0$.0! & $<0.018 \mid$ & - & & $\begin{array}{l}68.85 \\
1138.7 \mathrm{~W}\end{array}$ \\
\hline 27 & $1<0.194$ & $10.45 \frac{7}{2}$ & $1<0.0000$ & $1<1.0018$ & $1<0.0101$ & $1<0.262$ & $\cdots$ & -- & 0.058 & {$[<0.0026$} & $|<0.0051|$ & & & $\begin{array}{l}T 56.25 \\
1636\end{array}$ \\
\hline 28 & $1<0.487$ & $2.0 \frac{+4}{9}$ & 16 & $<0,007$ & .035 & 30 & - & $=-$ & $\leq 0.077$ & 19 & 16 & & $=$ & $\begin{array}{l}160.25 \\
159.24\end{array}$ \\
\hline 29 & $1<0.202$ & $0.62 \frac{+5}{4}$ & $\mid<0.0008$ & $\leq 0.002$ & $\mid<0.011$ & $1 \leq 0.207$ & $.01 \frac{+14}{43}$ & & 0.197 & $\mid<(0.0) 09$ & $\mid<0.024$ & $\begin{array}{r}+30 \\
.0082 \\
\end{array}$ & $\left\{\begin{array}{l}+38 \\
0.0 \overline{0} ; 6\end{array}\right.$ & $\begin{array}{l}T 595 \\
159.2 \mathrm{~W}\end{array}$ \\
\hline 30 & $1<0.437$ & $1.00^{ \pm 6}$ & $1<0.001$ & $1 \leqslant 1.003$ & $1<0.020$ & $\leq 11.508$ & $=-$ & $0.01 \frac{23}{43}$ & 10.0775 & $1<0.006$ & $1<0.010$ & - & -- & $\begin{array}{l}749.9 \mathrm{~s} \\
174.2 \mathrm{~W}\end{array}$ \\
\hline 31 & $1<0.232$ & $10.88 \frac{+4}{2}$ & 67 & $i<0.002$ & 0.013 & $\therefore 336$ & -- & & $0.03 \frac{+15}{9}$ & iso. & $<0.005$ & $=$ & $\cdots$ & $\begin{array}{l}46.15 \\
174.8 \mathrm{~W}\end{array}$ \\
\hline 32 & $1<0.256$ & \pm 3 & 0.19006 & $\mid<0.0012$ & $1<0.015$ & 60.474 & & & & $1<0.002$ & $1<0.005$ & - & 0.00257 & $\begin{array}{l}42.25 \\
174.4 \mathrm{~W}\end{array}$ \\
\hline 33 & $\mid<0.289$ & 1.84 & $|20,00016|$ & $\leq 0.0012$ & $\leq 0,012$ & $<11.428$ & -- & -- & $\left\{\begin{array}{l}+13 \\
0.0575\end{array}\right.$ & & $1<0$ & $\cdots$ & $0.00 \frac{+12}{30}$ & $\begin{array}{l}37.65 \\
3173.96\end{array}$ \\
\hline 34. & $1<0.767$ & $13.55^{+2}$ & |<u. & $1 \leq 0.005$ & k<0.039 & $\mid<1.31$ & -- & $\because$ & $10.06 \frac{+20}{8}$ & $<0$. & .013 & - & -- & $\begin{array}{l}734.45 \\
172.36\end{array}$ \\
\hline 35 & $i<1.34$ & 15.26 & $|<0,(1)(0) 4|$ & $1<0.0106$ & $1<0.1165$ & $<2.48$ & - & & $10.13 \frac{16}{4}$ & $1<0.008$ & 220 & - & 10.0058 & $\begin{array}{l}31.2 \mathrm{~S} \\
772.1 \mathrm{~W}\end{array}$ \\
\hline 37 & $1<0.720$ & $11.11^{ \pm 4}$ & $\mid<1) .010 !$ & $\mid<0.0103$ & $1<0.036$ & $1<1.56$ & $z-$ & & $10.08 \frac{18}{39}$ & $<0.004$ & $1<0.010$ & & $10.00 \frac{18}{42}$ & $\begin{array}{l}78.6 \mathrm{~S} \\
7175.8 \mathrm{~W}\end{array}$ \\
\hline 38 & 787 & $13.58^{+2}$ & $\{(\}, 0)$ & 114. & $7 y$ & 37. & & & $\begin{array}{r}+36 \\
0.0394\end{array}$ & & & & & $\begin{array}{l}135 \\
177.2 \mathrm{~W}\end{array}$ \\
\hline 39 & $\leq 1.54$ & 11.25 & $\mid<0.80108$ & $<0.003$ & 10.0164 & $\leq 1.22$ & 10,0028 & $=-$ & 10 & $1<0.0012$ & 21 & $\because$ & 10. & 4181.016 \\
\hline 40 & $\left\{\begin{array}{l}100.865 \\
\end{array}\right.$ & $1.84^{ \pm]}$ & $<0.1101$ & $<0.004$ & $\leq 0.050$ & $1<1,71$ & $\cdots$ & - & $10.218^{+8}$ & $1<0.0005$ & 100 & -- & 10.00784 & $\begin{array}{l}9145 \\
41846\end{array}$ \\
\hline
\end{tabular}


our conclusion is that because the $95_{\mathrm{Nb}}$ is associated with the ${ }^{144} \mathrm{Ce}$ in our samples, is knum to be highly concentrated by plankton, and is detected by Battelle in th. air samples, it is real and its association with the $238_{\mathrm{U}}$ is also real.

As with the ${ }^{144} \mathrm{Ce}$, there is a relationship between the $95 \mathrm{Nb}$ found in the air filters and in the plankton. We $\mathrm{f}$ ind positive indications of $95 \mathrm{Nb}$ in both plankton and air samples from the same laticude bands of $20^{\circ} \mathrm{Y}$ to $40^{\circ} \mathrm{S}$ on the southern leg of the cruise. Plankton, however, show two other positive results: in the same $60^{\circ}-$ $70^{\circ} \mathrm{S}$ latitude band as the ${ }^{144} \mathrm{Ce}$ and other radionuclide and at $8^{\circ} \mathrm{S}$ (Station 39 , northwest of lima), which could represent material in the Peruvian current. This last sample, while lacking confirmation in either the air or water samples, has the lowest $238 \mathrm{U}$ concentration of the ${ }^{95} \mathrm{Nb}$ group and the identification is quite positive. Water samples from near this station were reported by Batelle to contain $110 \mathrm{~m} \mathrm{Ag}\left(4.7 \mathrm{dpm} / \mathrm{m}^{3}\right)$ and $15 \mathrm{E}_{\mathrm{Eu}}\left(5.8 \mathrm{dpm} / \mathrm{m}^{3}\right)$.

The only published data we could find even remotely confirming our results are those of Kolesnikova et 21.22 from 1969 in the region of Mururoa Atoll. They reported finding $141 \mathrm{Ce}$ in planktion at levels of $0.28-5.6 \mathrm{pCi} / \mathrm{g}$-wet, ${ }^{144} \mathrm{Ce}$ at $0.16-$ $4.0 \mathrm{pCi} / \mathrm{g}$ wet, ${ }^{103} \mathrm{Ru}$ at $0.2-4.0 \mathrm{pC} / \mathrm{g}$-wet and $95 \mathrm{Zr}$ at $0.24-9$, $\mathrm{ii} / \mathrm{g}-$ wet. These concentrations are much higher than we found bucause of nuclear testing at the time, but indicate that Mururoa could be a source of radionuclides to the Southern Ocean. Fig. 6 shows all of our plankton stations; those where ${ }^{95}$. vb and/or ${ }^{144}$ Ce were detected are circled.

Figure 7 shows the ${ }^{7} \mathrm{BE}$ concentration in both plankton and associated air filters on a station-by-station basis. $7_{\text {Be }}$ is produced by spallatian reactions of cosmic rays on atmospheric constituents at high altitudes and, except for thermonuclear explosions, has no significant anthropogenic source. Because ${ }^{7}$ Be has a half-life of only 53 days, we were able to detect it only in the samples returned from New Zealand. All the other samples returned with the ship either had very low 7 Be concentrations to begin with, or it had decayed below detection 


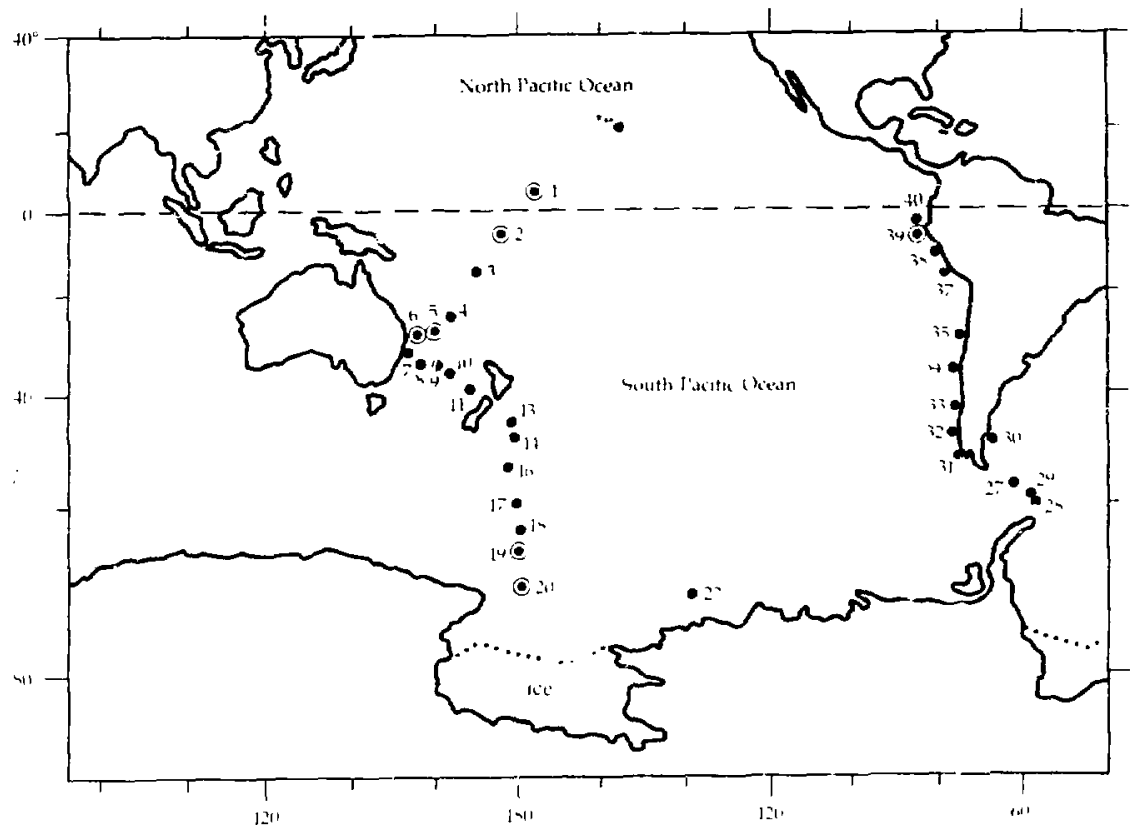

Figure 6. Plankton stations for Operation Jecpireoze 1981 . 95 nb andor 14 't $C$ were detected a: the stations circled.

levels before countias (this also could have been the casc for $95 \mathrm{Nb}$ ). The plot does show the association between high concentrations in air and plankton for the trip south. 7 be was not detected in plarkton wh:n the air concentration was bolow about $500 \mathrm{dpm} / \mathrm{sample.} \mathrm{The} \mathrm{average} 7$ Be concentration in plan ion be tiwcen $28^{\circ}$ and $39^{\prime \prime} \mathrm{S}$ was $0.316+0.10 \mathrm{pCi} / \mathrm{s}$ wet, while the average concentration measturad by Battelle in filtered sea water from these latitudes was $(114+34) 13^{-6}$ pCi/g. This gives a conceatration factor for ${ }^{7}$ Be of $2770 \pm 1200$, which is in the tange generally observed for these factors, but somewhat iligher than the factor of lono reported by Lowman et a 1.34 


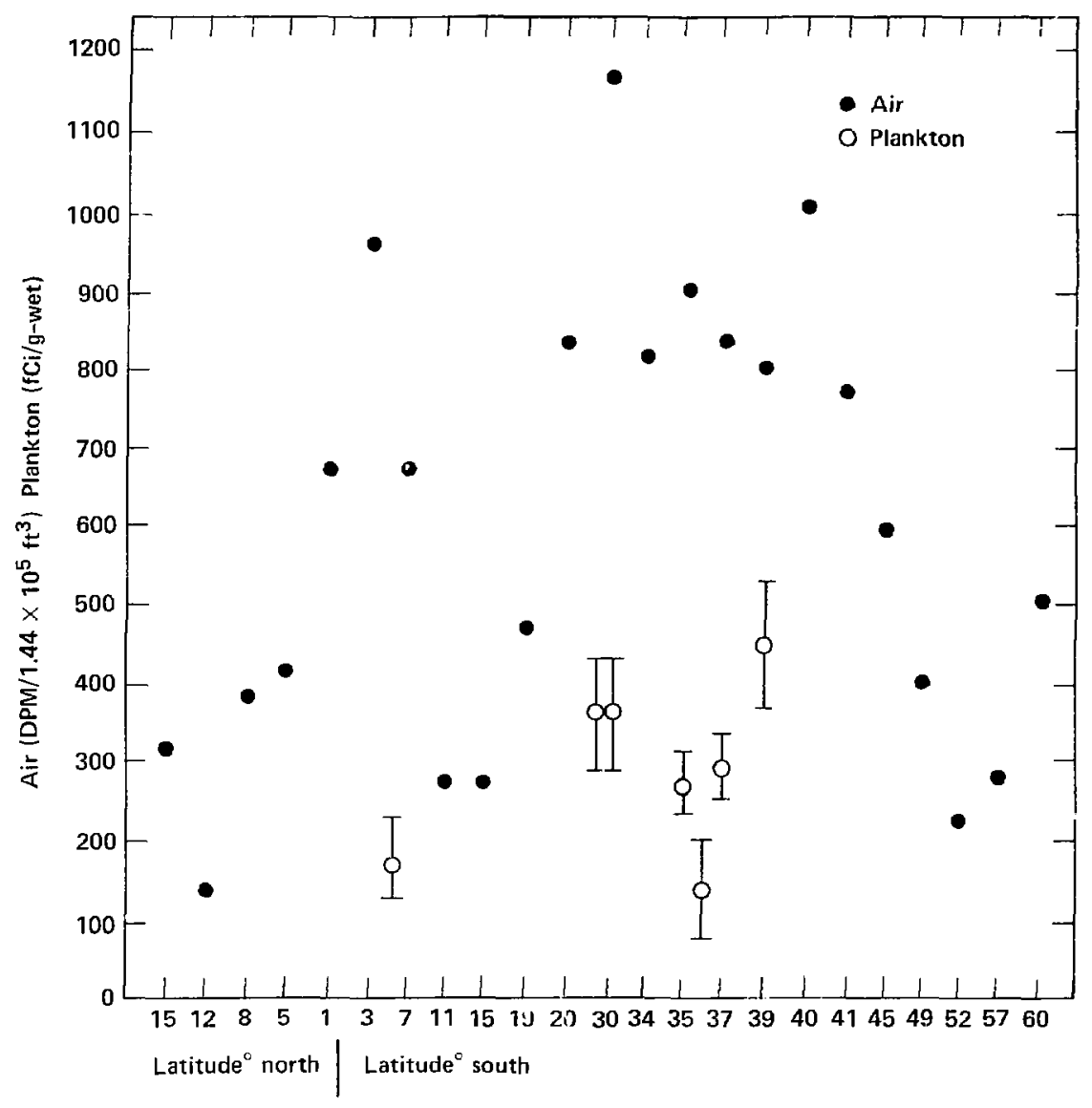

Vertical error bars are 10 counting error - error data not available for air.

Figure 7. 7 Be concentrations at individual stations. Vertical error bars are 1 o counting error (not available for air). 
of the long-lived naturally occurring radionuclides, $40_{\mathrm{K}}$ was detected in all 32 samples, $238_{U}$ in all but $1,226_{R a}$ in 11 , and $228_{R a-} 228_{T h}$ in 9 . The specific activity of $40 \mathrm{~K}$ is $0.84 \mathrm{pCl} 40_{\mathrm{K}} / \mathrm{mgK}$, which gives an average of about $1.4 \mathrm{mg} \mathrm{K}$ per gram of plankton vs $0.4 \mathrm{mg} \mathrm{K} / \mathrm{g}$ of average sea water or a concentzation factor of 3-4. Ten of the samples had enough $U$ to enabıe measurement of the ${ }^{23} \mathrm{U}$ isotope as well as the $238_{\mathrm{U}}$. The average activity ratio of the $238_{\mathrm{U}}$ to the $235_{\mathrm{U}}$ in these samples was 22.3 in good agreement with that in sea water, 21.8. This implies that if the ratio were much different, for whatever reasons, it would be apparent in the plankton. The average $U$ specific activicy in plankton from Table 1 is $0.619 \pm 1.2 \mathrm{pCi} / \mathrm{g}$ while sea water is known to be about $0.001 \mathrm{pCi} / \mathrm{g}$. This gives an average concentration factor of about 600 , ranging from less than 100 to over 1000 . In any event, the concentration factor for normal id is very favorable and would be expected to apply to other isotopes of $\mathrm{U}$ from whatever source. We were pleased to see the $\mathrm{Ra}$ isotopes in low concentrations because their decay products, especially ${ }^{214} \mathrm{~Pb}-214 \mathrm{Bi}$, have a large number of intense and energetic gamma rays that could seriously interfere with the detection of low levels of other radionuclides.

While the method used for calculating upper limits fur undetected radionuclides has been described, a number of factors enter into the final result. It must be remembered that gamma spectrometry is simply the observation of ilea spontaneously enfted gamma rays from the sample. The only means of increasing sensitivity are to count large samples. to count the samples as close to the detector as possible (somewhat mutually exclusive), to count for as long as possible and to minimize the decay time between sample collection and analysis. The background in the energy region of interest is important and is composed mostly of Comptorscattered photons from higher energy gamma rays emitted by radionuclides in the sample. The Compton suppression circuitry in our counter reduces this background by a factor of 5 to 20 , depending on energy. Other factors that tend to minimize the upper limit calculated for a particular nuclide are large sample weight, ciosein geometry, short decay time, large branching intensity for the gamma ray sought, 
and absence of othcr gamma rays at higher energy. It can be seen, then, that the upper limit for detection of a particular radionuclide varies from sample to sample and can be widely different from one radionuclide to the next. This explains, for example, why the uiper Iimit for ${ }^{7} \mathrm{~B} !$ is higher in the later samples. All numbers are decay-corrected to Decomber 1 , 1.981, so the samples counted in February have smaller decay corrections than those fnalyzed in June.

It is interesting to note the low 1 imits of detection for the nuclides $54 \mathrm{Mn}$ and $65 \mathrm{Zn}$, and the implication these limits have on sensitivity. The decection limits are about $\mathrm{I} \mathrm{fCi} / \mathrm{g}$, and we would like to have about ten times this for a good measurement, say, $10 \mathrm{fCi} / \mathrm{g}$. Assuming a very conservative concentration factor of $10^{3}$ for these two nuclides, we would be able to measure concentrations in sea water at least as low as $10 \mathrm{fCi} / \mathrm{l}$ (about $20 \mathrm{dpm} / \mathrm{m}^{3}$ ), probably even lower.

Table 2 lists the results of our species identification work on the plankton. The method of pumping through the ship's fire mains and collecting for 24 h or more resulted in samples containing many broken pieces and in some cases only fragmented exoskeletons with no soft parts remaining, making identification difficult. At this stage of our experience, we are unable to say much about the influence of species compositiun on radionuclide content, and Table 2 is included principully to present the data. The samples generally consist mostly of copepods with varying amounts of faraminifera and lesser amounts of other organisms. It is interesting that only 13 samples contained 10 or more foraminifera, and 6 of the 7 samples containing either $95 \mathrm{Nb},{ }^{144} \mathrm{Ce}$, or both are included among these. While so few samples hardly represent a statistically significant number, possibly what we are seeing is the influence of the generally higher specific activity of smaller particles as reported by the UW groups. As data from future cruises a cumulate, perhaps corrections will become more definite. A side benefit of the species analysis is that it alerts us to contamination by nonplanktonic mateilal, such as sessile organisms or inorganic detritus. A summary of the seven samples containing $95 \mathrm{Nb}$ and/or $144 \mathrm{Ce}$ with a description of the principal biomass is given in Table 3 . 
Table 2.

Plankton species. ${ }^{a}$

\begin{tabular}{|c|c|c|c|c|c|c|c|c|c|c|c|c|c|c|c|}
\hline $\begin{array}{c}\text { Sample } \\
\text { Naxa }\end{array}$ & 1 & 2 & $3^{c}$ & 4 & $5^{b, d}$ & 6 & $7^{E}$ & 8 & 9 & 10 & 11 & 1.7 & 16 & 17 & 18 \\
\hline \multicolumn{16}{|l|}{$\begin{array}{r}\text { Crustacea } \\
\text { Copepods }\end{array}$} \\
\hline Calanodds & & & & & & & & & & & & & & & \\
\hline $\begin{array}{l}\text { Calanus Sp, } \\
\therefore . \text { Propinquus }\end{array}$ & 341 & 4510 & 310 & $4: 40$ & 2780 & 3080 & 103.3 & 400 & 82 & 248 & 276 & 36 & 799 & 713 & 128 \\
\hline Landacia & 60 & 60 & 30 & -- & 290 & 30 & 30 & - & $-\rightarrow$ & -- & 4 & 10 & 1 & -- & -- \\
\hline Temora $S_{p}$. & -- & 60 & $-\infty$ & -- & 4610 & 4760 & 5760 & 1860 & -- & -- & -- & 76 & -- & -- & $\rightarrow$ \\
\hline Labidocera $S_{P}$. & - & -- & 80 & - & 190 & -- & 30 & - & -- & -- & -- & -- & -- & -- & -- \\
\hline Euchaeta sp. & 3 & 380 & 70 & 120 & 290 & 130 & -- & -- & -- & -- & -- & -- & -- & -- & -- \\
\hline Metridia Sp. & -- & - & - & - & -- & 30 & -- & -- & -- & 16 & -- & 72 & 1 & -- & -- \\
\hline Scolecithrix Sp. & -- & - & - & - & -- & -- & -- & -- & -- & -- & -- & - & -- & - & -- \\
\hline Pontella $\mathrm{Sp}$. & - & -- & - & -- & -- & -- & & -- & -- & -- & -- & -- & -- & $\rightarrow$ & $\rightarrow$ \\
\hline Eucalanus & - & -- & - & -- & -- & -- & -- & -- & -- & - & -- & -- & -- & -- & -- \\
\hline Pleuromanima $5 p$. & 1 & 120 & 60 & 400 & 540 & - & -- & 1030 & 11 & 284 & 224 & 5 & -- & -- & -- \\
\hline Centropages $\mathrm{Sp}$. & 60 & 60 & 40 & 10 & 470 & 90 & 120 & - & -- & -- & -- & -- & -- & -- & -- \\
\hline Unident Large & - & 60 & 170 & - & 420 & + & 700 & -- & -- & -- & -- & 37 & -- & 4 & -- \\
\hline Untdent Smali & 1220 & 6300 & - & 40 & -- & 290 & -- & -- & -- & -- & -- & - & 1612 & 674 & 1496 \\
\hline Calanotdes & - & - & $\cdots$ & - & -- & - & $-\infty$ & -- & $\rightarrow$ & - & -- & 2 & - & -- & -- \\
\hline Cyclopolds & 3426 & 11850 & $1175 \mathrm{u}$ & 190 & 2040 & 550 & 380 & 160 & 0 & 12 & 26 & 1 & -- & -- & -- \\
\hline Copilia & $\ldots$ & $\rightarrow$ & $\rightarrow$ & -- & -- & -- & 30 & -- & -- & -- & -- & -- & -- & -- & -- \\
\hline Harpactocolds & 540 & 1900 & 20 & -- & 60 & 160 & -- & -- & -- & -- & 16 & -- & -- & -- & -- \\
\hline Cammerid Amplilpod & - & $\ldots$ & - &.- & - & - & -- & -- & -- & -- & -- & -- & -- & -- & - \\
\hline Amph1pods & - & - & 10 & 40 & 30 & -- & -- & 30 & 25 & 3 & 2 & 5 & 19 & 4 & 8 \\
\hline Caprellids & $\cdots$ & -- & - & - & -- & -- & -- & -- & -- & -- & - & -- & $-\cdots$ & $\cdots$ & 4 \\
\hline Fuphausild pleces & - & $\cdots$ & 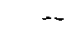 & - & 15 & -- & $\mathrm{l}$. & 10 & 12 & 3 & 18 & -- & -+ & -- & - \\
\hline Euphasidd Nauplis & 1 & 2613 & 50 & 40 & 60 & 100 & 100 & 220 & 40 & - & 44 & 43 & -- & 4 & 8 \\
\hline Euphausid Calyptopis & - & - & $-\infty$ & -- & $\rightarrow$ & -- & -- & $\rightarrow$ & -- & -- & -- & 11 & $-\infty$ & 6 & $-\infty$ \\
\hline Megalops & $\cdots$ & -- & 20) & 40 & 60 & 60 & -- & -- & 2 & -- & -- & -- & -- & -- & \\
\hline Zoeas & -- & $\cdots$ & & & & & -- & -- & -- & -- & -- & - & $\rightarrow$. & $-\infty$ & -- \\
\hline Nauplid & $\cdots$ & - & $-\infty$ & -- & -- & -- & -- & -- & -- & -- & -- & -- & 1 & -- & -- \\
\hline Astracods & - & - & 20 & 30 & 30 & -- & -- & 20 & 1 & -- & 4 & I & 14 & 29 & 8 \\
\hline Barnacle nauplit & 60 & - & - & 30 & 30 & -- & -- & - & -- & -- & -- & $-\infty$ & $=$ & - & -- \\
\hline Barnacle: Cyprtds & $\cdots$ & - & -- & -- & $-\cdots$ & -- & - & -- & -- & -- & -- & -- & $=$ & -- & -- \\
\hline Isopods & - & $\cdots$ & - & - & $-\cdots$ & - & -- & - & -- & -- & -- & -- & -- & -- & $-m$ \\
\hline
\end{tabular}

Pumber of individuals per $25 \mathrm{ml}$.

Artificial radlonuclider decected in these samples. 
Table 2 (continued).

Plankton species.

\begin{tabular}{|c|c|c|c|c|c|c|c|c|c|c|c|c|c|c|c|}
\hline Sample No. & 1 & 2 & 3 & $\therefore$ & $\underline{s}$ & $6^{e}$ & $7^{6}$ & $\underline{8}$ & $\underline{9}$ & 10 & 11 & 13 & 16 & 17 & 18 \\
\hline RadLolartans & $-\cdots$ & 1000 & -- & - & -- & -- & - & -- & -- & - & - & -- & - & -- & $=$ \\
\hline Foraminifera & 1410 & 1900 & -- & 20 & 190 & 160 & 160 & - & 1 & $\cdots$ & 10 & -- & $-\infty$ & 19 & 376 \\
\hline Mollusra & -- & -- & -- & -- & -- & -- & -- & - & -- & $-\cdots$ & - & -- & - & -- & - \\
\hline Gastropod Larvae & -- & -- & -- & -- & 30 & -- & - & -- & -- & -- & -- & -- & -- & -- & - \\
\hline Pteropods & 740 & 2400 & 40 & 90 & 770 & 60 & 60 & 60 & 1 & 12 & 20 & -- & $m$ & - & - \\
\hline D1acrla Quadridentat & -- & -- & -- & $\rightarrow-$ & -- & -- & $\rightarrow-$ & -- & -- & -- & -- & -- & 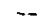 & -- & - \\
\hline Creseis Virgula & 130 & -- & -- & -- & 320 & 510 & 510 & 100 & -- & -- & -- & -- & -- & -- & -- \\
\hline LINACINA INFLATA & -- & -- & -- & -- & -- & -- & -- & -- & -- & $\cdots$ & -- & -- & - & -- & - \\
\hline L. Bulimoldes & - & -- & -- & -- & -- & -- & -- & -- & -- & -- & -- & -- & -- & -- & -- \\
\hline L. Hellcina & $\rightarrow$ & -- & -- & -- & - & -- & -- & - & -- & -- & - & -- & 48 & 59 & 416 \\
\hline Slphonophore & $-\infty$ & - & 40 & 30 & 60 & 30 & 30 & $-\infty$ & 5 & -- & -- & -- & $\cdots$ & -- & - \\
\hline Chaetognaths & 60 & 60 & 60 & 210 & 100 & 320 & 160 & 50 & 3 & 8 & 64 & 6 & 6 & 6 & - \\
\hline Salp & -- & -- & 10 & -- & 60 & -- & 1340 & 20 & -- & -- & -- & 1 & -- & -- & - \\
\hline Fish Eggs & 350 & 450 & 180 & 880 & 19700 & 640 & - & 80 & 62 & 8 & 28 & 6 & -- & - & $\rightarrow$ \\
\hline Vartous Larvae & 690 & 2450 & 50 & 610 & 830 & 1372 & 1370 & 50 & 4 & - & 4 & - & - & -- & - \\
\hline Centric Diatoms & -- & -- & -- & -- & - & -- & -- & $m$ & -- & -- & -- & -- & -- & -- & $\cdots$ \\
\hline
\end{tabular}

c Shrimp Lucifer Sp. - 10.

d Heteropods - 60; Cladocera - 220 .

e Cladocera - 260 .

f Claducera - 260; Shrimp Lucirler Sp. - 30. 
Table 2 (continued).

Plankton species.

\begin{tabular}{|c|c|c|c|c|c|c|c|c|c|c|c|c|c|c|}
\hline Sample & $19^{\dagger}$ & $20^{\prime}$ & 22 & 27 & 28 & 30. & 31 & 32 & 33 & 34 & 35 & 37 & 38 & $39^{b}$ \\
\hline \multicolumn{15}{|l|}{$\begin{array}{r}\text { Crustacea } \\
\text { Copepods }\end{array}$} \\
\hline \multicolumn{15}{|l|}{$\begin{array}{l}\text { Copepods } \\
\text { Culanoids }\end{array}$} \\
\hline Calanus Sp. & 12 & -- & -- & 1604 & 3 & 104 & 824 & 2888 & 923 & 380 & $1) 8$ & 4 & 2 & -- \\
\hline C. Proplnquus & -- & -- & -- & -- & 1 & -- & -- & -- & -- & $-\infty$ & -- & 600 & -- & -- \\
\hline Candacia & 20 & - & -- & -- & - & $9 \times 2$ & 1464 & 144 & 80 & 44 & 500 & - & -- & 3974 \\
\hline Temora Sp. & - & - & -- & -- & -- & -- & -- & -- & -- & 8 & 84 & - & 144 & 506 \\
\hline Labidocera $\mathrm{Sp}_{\mathrm{p}}$. & -- & -- & -- & -- & -- & $-\infty$ & -- & -- & -- & 4 & -- & - & -- & 196 \\
\hline Euchaeta SY. & -- & - & -- & -- & -- & -- & -- & -- & -- & -- & -- & -- & -- & -- \\
\hline Metridia sp. & -- & 4 & -- & -- & 4 & 256 & -- & 1328 & 352 & 352 & 8 & - & -- & -- \\
\hline Scolecithrix Sp. & -- & -- & - & -- & -- & -- & -- & -- & -- & 100 & 120 & 124 & 50 & 111 \\
\hline Pontella Sp. & -- & $-\infty$ & $-\infty$ & -- & - & -- & -- & -- & -- & -- & -- & 132 & -- & 2 \\
\hline Eucalanus & -- & $-\infty$ & - & -- & -- & - & -- & -- & -- & -- & 4 & 608 & 20 & -- \\
\hline Pleuromamua $S_{p}$. & -- & -- & -- & -- & - & -- & -- & -- & 48 & 16 & - & -- & -- & -- \\
\hline Centropages $\mathrm{sp}$. & -- & -- & -- & -- & -- & -- & - & 1344 & 5152 & 220 & 8 & 448 & 2004 & -- \\
\hline Onident Large & -- & - & -- & -- & - & - & 24 & -- & 32 & 16 & 12 & 4 & -- & 272 \\
\hline Unident Small & 120 & -- & -- & 852 & 32 & 5488 & 368 & 15000 & 47800 & 126 & 2012 & 164 & 1140 & 5895 \\
\hline Calanoldes & -- & $-\vec{x}+x+a+a$ & -- & -- & $\cdots$ & -- & -- & -- & -- & $\therefore$ & -- & 12 & $\vec{a}$ & 288 \\
\hline Cyclopoids & -- & 1 & -- & -- & - & 8 & 108 & -- & 1112 & $1 \$ 2$ & 56 & 584 & 34 & 3118 \\
\hline Copilia & -- & -- & -- & -- & -- & -- & -- & -- & -- & 4 & 4 & 4 & -- & 1 \\
\hline Harpactocoids & -- & - & -- & -- & -- & -- & -- & -- & 16 & 4 & -- & -- & 2 & 44 \\
\hline Gannerld Amphipod & -- & - & -- & -- & -- & -- & -- & -- & -- & - & -- & $\overrightarrow{-}$ & -- & -- \\
\hline Amphipods & -- & -- & 4 & 52 & 5 & 8 & 20 & 232 & -- & 4 & 4 & 16 & $\cdots$ & 1984 \\
\hline Caprellids & 20 & 3 & - & -- & -- & 8 & 8 & -- & - & -- & - & - & - & $\rightarrow$ \\
\hline Fuphauslid Pleces & -- & $\cdots$ & 4 & - & - & -- & -- & 16 & -- & .. & -- & -- & -- & 1 \\
\hline Euphausidd Naupli i & 4 & - & -- & -- & - & -- & -- & -- & -- & - & -- & -- & -- & -- \\
\hline Euphausidd onlyptopis & -- & -- & -- & -- & $\cdots$ & -- & . & 8 & 24 & 152 & -- & 24 & -- & $\rightarrow$ \\
\hline Megilops & -- & -- & -- & -- & -- & -- & -- & -- & -- & -- & - & -. & -- & -- \\
\hline Zoezs & -- & - & -- & -- & - & -- & -- & 16 & 16 & 148 & 12 & - & 4 & 17 \\
\hline Naupli1 & -- & -- & -- & -- & - & 16 & -- & 3? & -- & 8 & 36 & 12 & 2 & -- \\
\hline Cstracods & -- & $-\infty$ & -- & 16 & - & 24 & 12 & $\because$ & -- & 12 & 4 & -- & -- & 33 \\
\hline Barmacle Nauplii & -- & -- & - & - & -- & -- & -- & $\mathrm{g}$ & 64 & 88 & $10 m$ & 12 & 4 & 24 \\
\hline Barnacle Cyprids & $\cdots$ & $-\cdot$ & -- & -- & - & -- & -- & 24 & 24 & 4 & 4 & 4 & 2 & -- \\
\hline isopods & -- & 1 & -- & - & -- & $-\cdots$ & $=-$ & 8 & $-\cdots$ & -- & -- & - & - & -. \\
\hline
\end{tabular}


Table 2 (concluded).

Plankton species.

\begin{tabular}{|c|c|c|c|c|c|c|c|c|c|c|c|c|c|c|}
\hline Taxa Sample II & 19 & 20 & 22 & $2 ?$ & 28 & 30 & 31 & 32 & 33 & 34 & 35 & 37 & 38 & 39 \\
\hline Radiolarians & -- & -- & -- & -- & -- & -- &.- & -- & -- & -- & -- & 4 & -- & -- \\
\hline Foramlnifera & 16 & -- & -- & -- & -- & -- & $\cdots$ & 8 & 112 & 24 & 4 & -- & -- & 539 \\
\hline Mollusca & -- & -- & -- & -- & -- & -- & -- & -- & -- & -- & -- & -- & -- & -- \\
\hline Pteropods & -- & -- & -- & -- & -- & -- & -- & -- & -- & -. & -- & -- & -- & -- \\
\hline Dlacrla Quadridentat & -- & . & - & -- & - & -- & -- & $-\cdots$ & - & $\cdots$ & -- & -- & - & -- \\
\hline Creseis Virgula & -- & -- & -- & -- & -- & -- & - & -- & -- & - & -- & -- & -- & - \\
\hline LInacina lnflata & $\cdots$ & 1 & 2 & -- & -- & -- & -- & 24 & 16 & -- & - & -- & - & 296 \\
\hline L. Bulimoldes & -- & - & -- & -- & -- & - & - & -- & -- & $\cdots$ & -- & -- & -- & -- \\
\hline l. Helicina & 4 & 5 & -- & - & -- & - & -- & 24 & $-\infty$ & - & - & -- & - & - \\
\hline Stphonophore & -- & -- & -- & - & -- & -- & -- & - & -- & -- & - & -- & -- & -- \\
\hline Chaetognaths & -- & - & - & 4 & -- & - & 56 & B & 32 & 100 & 64 & 52 & 4 & 257 \\
\hline $\operatorname{Sal}_{p}$ & -- & - & 2 & - & -- & -- & -- & -- & -- & -- & -- & -- & - & - \\
\hline FIsh Eggs & -- & - & -- & -- & -- & -- & -- & 968 & 312 & 408 & 76 & 204 & 84 & 75 \\
\hline Various Larvae & -- & -- & -- & -- & -- & -- & -- & - & -- & -- & -- & -- & - & -- \\
\hline Centric Diators & - & - & 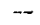 & -- & - & -- & 12 & 256 & -- & 32 & 12 & -- & - & -- \\
\hline
\end{tabular}


Tabl: 3 .

Sumary of hionass associated with artificial radionuclides.

\begin{tabular}{|c|c|c|}
\hline Sample & kadionuclides & Desieri,lion of Principal Bionass \\
\hline 1 & $95 \mathrm{Nb}-14^{4} \mathrm{Cl}$ & $\begin{array}{l}\text { Cyclopoids, algae, sholl } \\
\text { fatgments, rust }\end{array}$ \\
\hline 2 & $95 \mathrm{Nb}-144 \mathrm{Ce}$ & $\begin{array}{l}\text { Approximately equal numbers } \\
\text { of calannids and cyclopoids. } \\
\text { Only sample with substantial } \\
\text { number of radiolarians }\end{array}$ \\
\hline 5 & ${ }^{14+4} \mathrm{Ce}$ & $\begin{array}{l}\text { Only sample with very large } \\
\text { friction of rish eggs }\end{array}$ \\
\hline 6 & $95 \mathrm{inb}^{\mathrm{i}}$ & $\begin{array}{l}\text { Other thar copepods, has large } \\
\text { contribution from latvaceans }\end{array}$ \\
\hline 19 & $95 \mathrm{Nh}-144 \mathrm{Ce}^{2}$ & $\begin{array}{l}\text { Mostly unidentifled small } \\
\text { calanoids, caprellids }\end{array}$ \\
\hline 20 & $95 i s h-144 c c$ & $\begin{array}{l}\text { About equal fraction of calanoids, } \\
\text { caprellids and pteropods }\end{array}$ \\
\hline 39 & $95 \mathrm{k}$ & $\begin{array}{l}\text { Substantial number of forams; } \\
\text { rust mostly smoll calanoids and } \\
\text { cyclopoids }\end{array}$ \\
\hline
\end{tabular}

a All samples contained Eorans and copepods except No. 20, which had no forams. 
The ocean is known to be a major source of atmospheric particulate matier. There is considerable evidence, however, that the chemical composition of the particles in the marine aerosol is often considerably different from that of seawater. Barker and Zeitlin 35 found enrichment factors for transicion metals in the aerosol approaching and exceeding three and four orders of magnitude relative t) sodium. Cattel1 and $\operatorname{Scott}^{36}$ suggest that a biogenic agrnt may be rocponsible for the approximately 20,000-fold enrichment of coppel during aerosol production in the ocean. The whole question of fractionation at the sea surface was the subject of a 1976 review article. 37 It seems possible, even likely, that the correlation we observe between radionuclides in plankton and in the air samples is due, at least in part, to resuspension. In general, we detect those, and only those, radionuclides in the air filters that are detected in the prankton at the same approximate location. Even the peculiarity of detecting only the $95^{\mathrm{Nb}}$ but not its parent, $95 \mathrm{Zr}$, is reproduced in the air filter data. While the air filter inlet was mounted as high as practical on the ship, its elevation above water level was only about 80 feet. Catteil and scott ${ }^{36}$ present evidence that, at least for copper, the influence of the marine aerosol extends upward to $2000 \mathrm{~m}$. If this is true, and given the sea surface conditions usually encountered in the Southern Ocean, it seems likely that most of the atmospheric particulate material we sampled was produced by resuspension. The air filters, however, often do show radioactivity not found in the plankton. This is probably because the air filter can collect the particles from a very large voíume of air without reducing the gamma dettction efficiency. If the smaller particles, $0.4 \mu \mathrm{m}$, or loss are also collected, evidence suggests these may have very high enrichment factors. It seems likely that low-altitude air filter sampling could be a very sensitive technique for montoring contamination in the sea as long as one realizes that it is principally the resuspended marine 
aerosol that makes up the bulk of the sample, not primarily atmospheric constituents. The only published work we have found to date indicating concentration effects for radionuclides is that of Patenden et a 1.38 They present evidence that Pu isotopes, 24$]_{\mathrm{Ann}}$ and ${ }^{137} \mathrm{Cs}$, are present in airborne material deposited in west Cumbria near Nindscale and downwind from the Irish Sea. "lost of the excess $137 \mathrm{Cs}$ can ba explained by controbutions from Nindscale discharges co air and material in sea water resuspended as spray. The excess actinites cannot bu explained in tarms of bindscale discharges to air and: "Some inconelusive evidence suggests tinat the excess actinides may come from a combination of (a) seaspray, raised by t'le wind from the sat surface which is (in sone way) higthly entiched with actinides (but not $137 \mathrm{Cs}$ ) compared to bulk seawater." loxcusses of $196 \mathrm{Ru}, 125 \mathrm{Sb}, 134 \mathrm{Cs}$, tad $144 \mathrm{ce}$ were also rbserved. It should be emphas ized that liueso radionuclides are initially tischiresed directly into the the water.

\section{BUTLEY AND COMCLUSAONS}

we have bryun an investigation ioto the potential utility of usimg nar' ae plankton ais indicators of low-level radisactive boncaminat ion in the Soutiern Decan. A review of the literature indicates that marine and frosi vater planiton, as well as other orynisms, can have concentration factors relative fo water ior

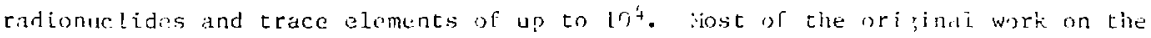

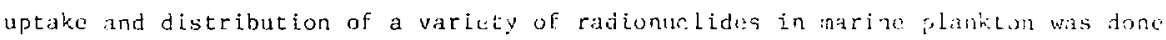
by the Intver: ity of Washington during the two atiuspheric nue lear list probrams in the :arshall tslands in 1956 and 1958. The work dumonstraterl that tnany radionuclides art: tapidly assinilatril by planktan with large concentration factors and recained within the biological strata ovar considerable time and distance. gther workers have confirmed thlse larg. comeentration factors and mesured atditional ones for a variety of elements and wrinisins. Very little work has been done in tho southern hemisphers, Jainly a fow studius in the region of lururoa Atoll. In 
addition to having high concentration factors, plankton is also easy to collect in international witers and simple to transport and analyze. Because of various uncontrollable factors, however, plankton is best used for detecting the presence of unusual radionuclides and measuring isotopic ratios.

Our cruise on che U.S.C.G.C. Glacier around the South Pacific Basin in 198182 resulted in the collection of 32 plankton samples along with numerous air filter, sea water, fallout and rain samples collected by Battelle Pacific Northwest Laboratory personnel. We were able to measure concentrations of ${ }^{7} \mathrm{Be}, 40_{\mathrm{K}}$ and $\mathrm{U}$ and $\mathrm{Th}$ series nuclides in some or all samples. Concentration factors were within the ranges expected, and we found that ${ }^{226}$ Ra and its decay products did not affect our ability to detect low levels of other radionuclides. The acrivity ratio of $238 \mathrm{U}$ t $235_{U}$ in plankton was the same as in sea water within experimental error. We believe we detected lok levels of $95 \mathrm{Nb}$ and $144 \mathrm{Ce}$ in seven samples from iocations as far south as $68^{\circ}$. While there is a potential for misidentification (especially in the case of $95 \mathrm{Nb}$ ) because of interference from other radionuclides, the facts that these same nuclides were detected independently by Battelle in the air filtors and sea water, and that they are known from previous work to have high concentration factors and to be associated in plankton, lead us to believe that they are real. We do not know the origin of these nuclides but note that they are high-yield fission products with good characteristics for high sensitivity of detection, and the levels we measured were very low. We calculated upper limit values for several radionuciides not detected, and these limits of a few fili/g indicate that we could measure a concentration of the order of $10 \mathrm{fCi} / \mathrm{l}$. in sea water.

The clase association of radionuclide content and concentration between the air filters and the plankton leads us to suspect that resuspension from the sea surface may strongly influence the aerosol composition. This effect has been reported in the literature for stable elements and suspected for radionuclides. Low-altitude air sampling could prove to be a very sensitive means of monitoring low levels of radionuclides in the sea. 
Biological identification of the plankton indicates that there may be an association between the artificial radionuclides and the foraminifea content of the samples. With only seven samples containing artificial radionuclides, this is a tentative conclusion, but it could be the result of the generally high specific activity of the snalicr plankton as reported by others.

\section{FURTHER STUDIES}

We have alroady participated in operation Deepfreoze 1982, a cruise simjlar to rhat in 1981, and the results wiil be the subject of part 2 of this report. ive will continue to collect plankton, water, and air samples in the southern hemisphere, utilizing ships of opportunity. We intend to investigate the extent to which ifurured is a source of radionuclides to the Southern ocean. We also intend to pursue the ida that samplino, the arine aerosol might be a very sensitive method for monitoring contamination in the sea.

We have reen exploring the possible utility of other marine organisins with the Commonwealth Scientific Industrial Resenreh Orjanization (CSiRU) llarine Laboratory in Perth, Australia, and have analyzed several samples of Ecklontia radiatia, a subtidal help, for possible use as a binconcentrator.

\section{ACKNOWLEDGMENTS}

We wish to express our thanks to Dr. Ved Wogman and his group at hat Pacific Northwest Laboratory for their assistance in pocurin? the space on the Glacier, for sollecting the samples at sian, and for supplying some w: tite tionres and dita.

This work is supported by the d. S. Department of Energy, Division of International Security Affairs. 
1. G. G. Polikarpov, Radioeklogiya Morskikh Organizmov (The Radioecology of Marine Organisms (Atomizdat, Yoscow, 1964).

2. J. E. Portmann, Ed., Manual of Mechods in Aquatic Environment Research, Part 2 - Guidelines for the Use of Biological Accumulators in Marine Pollution Hontiong, Food and Agricultural organization of the Jnited Nations, United Nations Fnvitonment Programe, FAO Fisheries Technical Paper No. 150 (1976).

3. J. J. Koranda and w. L. Robinson, "Accumulation of Radionuclides by Plants as a Monitor System," Environmental Health Perspectives 27, 165 (1978).

4. L. R. Donaldson, A. H. Seymour, E. E. Held, N. D. Hines, F. G. Lowman, P. R. Olson, A. D. Welender, Survey of Radioactivity in tne Sea Near. Bikini and Eniwetok Atolls, June 11-21, 1956, Applied Fisheries Laboratory, University of Washington, Seattle, Washington, UWFi-46 (1956).

5. J. H. Harley, Ed., Operation Troll, Health and Safecy ,aboratory, U. S. Atonic Energy Commission, New York Operations Office, Nro-4656 (1956.)

6. A. H. Seymour, E. E. Held, F. G. Lowman, J. R. Donalison, D. j. South, Survey of Radioactivity in the Sea aud in Pelagic Marine Life West of the Marshall Islands, September 1-20, 1956, Applied Fisheries Laboratory, University of Washington, Seatele, Washington, UWFL-47 (1957).

7. F. G. Lowman, Radionuclides in Plankton Near the Marshall Islands, 1956, Labotatory of Radiation Biology, University of Washington, Seattle, Washington, UWFL-54 (1958).

8. N. D. Hines, Proving Ground: An Account of the Radiobiologizal Studies in the Pacific, 1946-1961 (University of Washington Press, Seattle, 1962).

9. R. C. Bolles and N. E. Ballou, "Calculated Activities and Abundances of J235 Fission Products," Nuclear Science and Engjneering 5 (3), 156 (1959).

10. A. D. Welander and R. F. Palumbo, Radionuclide Content of Oceanic Fish, Plankton, and Jater in the Vicinity of Christmas Island, March through August, 1962, aboratory of Radiation Biology, University of Washington, Seattle, Washington, UWFL-88 (1963).

11. W. Feldt, G. Kanish, R. Laver, "Radioactive Contamination of the NEA Dumping Sites," Proc. Symp. Impacts of Radionuclide Releases into the Marine Environment, Vienna, 1980 (IAE.1-SM-248/111), pp. 465-480.

12. K. C. Pillai, R. C. Smith, T. R. Folsom, "Plutonium in the Marine Environment," Nature $203(49 / 5), 568$ (1964).

13. V. V. Gromov, "Uptake of Plutonium and Ot'ier Nuclear Wastej by Plankton," Marine Science Communications 2 (384), 227 (1976). 
14. V. S. Zlobin and 0. V. Mokanu, Mechanisms of the Accumulation of Plutonium-239 and Polonium-210 by the Brown Alga Ascophyllom Nodosum and Yarine Phytoplankton," Voprosy Morsk, Biol. (Problems of Iarine Biclogy) 12, 160 (1969).

15. S. W. Fowler and S. R. Aston, "Application of 235 sp in Experimental Aquatic Radioecology: Preliminary Observatione on ieptunium Behaviour in ica Water, Sed:ments and Zouplankton," Health Physics 42 (4), 515 (1982).

15. L. V. Shannon, The Alpha-Activity of :larine Plankton, Repuilic of bouth Afric. Departinent of Industries, Division or Sea Fisheries Investigational Report $\therefore$. 68 (1969).

17. A. S. Paschoz, F. 3. Baptist:1, 1. E. IJenn, and Y. Eisuruud, "Dosinetry of Natural and :lan-"ade Alpha Enitters in Plinkton," Pruc. Symp. Impacts of ladionuclide Releases into the larine rnvironment, loc. cit., pp. 69b-7l6.

18. L. V. Sick and C. J. Baptist, "Cadrium Incorporation by the Yarilie Copepod PEeudodiaptonus coronatus," Limnol. Oceanogr. 24 (3), 4j3-462 (i979).

19. K. Knauss, T. Ku, "The Flemental Composition and Decay-Series Radio auclide Content of Plankton From the Fast Pacific," Chemical Goology 39, 125-145 (1983).

20. T. Fisher, "Pioaccumulation of Terhnetium by Harine Phytoplankton," Envire Sci. [echnol. 16, 579-581 (198\%).

21. T. '?. Beasley, Biogeochemical Studies of Technetium in :Lrine and Estuarine

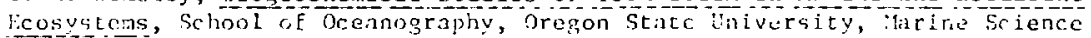
Center, towporl, Oregon. Dor/EV/11i251-3 (1981).

22. A. ‥ Kolesnikova, G. V. Barinov, 1. Ya. Zensenko, "Padior ological Investigation in th:- Region of Gurutud Atoll (Tuarintu Iiland), "Rndiobiologiya $\underline{9}(L), 139$ (1969).

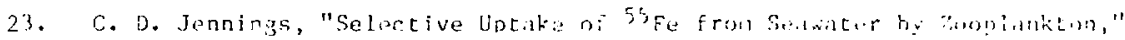
:1ar. Sci. Comm - 4 (1), 4i-jis (19/8).

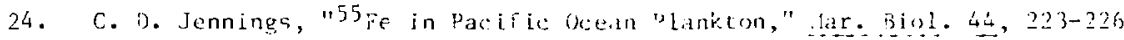
$(1977)$.

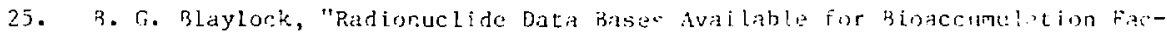
co1s For Freshwater Biuta," Nuclear Eafety 23 (4), 427 (1982).

26. I. Aoyama, K. Inomo, Y. Inoue, "Uptake ant Reless.. of Some Radinnurlides by Fresh Water Phytoplankton in Batch Cuiture," J. Radiat. Res. 17, 69-81 $(1976)$.

27. D. P. Marciulioniane, R. F. Dusauskiene-Duz, and C. A. Cibiraite: "Radioccological Study of the Charopinytes," Hydrobiol sical Journal 12 (1), 6-16 (1976).

28. T. A. Jenckes, The Feasibility of Using Phytoplankton : Setinad of Detecting Low Levels of Radionuclides, Ph. n. ihesis, Temple University, Philadelphia, PA (1975). 
29. J. B. Millard, F. W. Whicker, O. D. Markham, "Gamma Emitting Radionuclides of the Test Reactor Area Leaching Ponds," Ecological Studies on the Idaho National Engineering Laboratory Site 1978 Progres $=\overline{R e p o r t}, 0.0$. Markham, Editor, U. S. Department of Energy Idaho Operations Of Eice Radiological and Environmental Sciences Laboratory, IDO-12087 (1978).

30. J. J. Davis, Accumulation of Radionuclides by Aquatic Insects, Biology Laboratory, Hanford taboratories, General Electric Co., Richland, WA, HW-SA-2848 (1962).

31. D. C. Camp, C. Gatrousis, L. A. Maynard, "Low Background Ge(Li) Detector Systems for Radioenvironmental Studies," Nucl. Instrum. Methods 117, 189 (1974).

32. R. Gunnink and J. B. Niday, Computerized Quantitative Analysis by GammaRay Spectrometry, Lawrence Livermore National Laboratory, Livermore, CA, UCRL-51061, Vols. I-IV (1972).

33. R. W. Hoff, J. W. Meadows, H. D. Wilson, A. L. Prindle, R. Gunnink, K. 0. Hamby, "Analytical Program," Enewetak Radiological Survey, W. E. Nervik and R. Ray, Eds., USAEC Nevada Operations Office, Las Vegas, NV, NVO-140, VoI. L (1973), pP. 426-485.

34. F. G. Lowman, T. R. Rice, F. A. Richards, "Accumulation and Redistribution of Radionuclides by Marine Organisms," Radioactivity in the Marine Environment (National Academy of Sciences, Washington, D. C., 1971), p. 173 .

35. D. R. Barker and H. Zeitlin, "Metal-Ion Concentrations in Sea-Surface Microlayer and Size-Separated Atmospheric Aerosol Samples in Hawaii," J. Geophys. Res. 77 (27), S076 (1972).

36. F. C. R. Cattell and W. D. Scott, "Copper in Aerosol Particles Produced by the Ocean," Science 22, 429 (1978).

37. R. A. Duce and E. J. Hoffman, "Chemical Fractionation at the Air/Sea Interface," Ann. Rev. Earth and Planet Sci. 4, F. A. Donath, F. G. Stehli and G. W. Wetheri11, Eds. (Annual Reviews, Inc., Palo Alto, CA, 1976) pp. 187-228.

38. N. J. Pattenden, R. S. Cambray, K. Playford, J. D. Eakins, E. M. R. Fisher, "Atmospheric Measurements on Radionuclides Previously Discharged to the Sea," Proc. Symp. Impacts of Radionuclide Releases into the Marine Environment, loc. cit., pp. 695-716. 